\title{
Biological invasion risk assessment of Tuta absoluta: mechanistic versus correlative methods
}

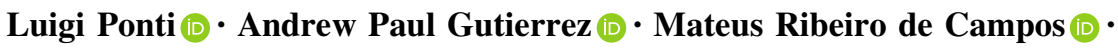 \\ Nicolas Desneux $\cdot$ Antonio Biondi $($ D $\cdot$ Markus Neteler $(\mathbb{D}$
}

Received: 2 January 2021 / Accepted: 27 July 2021 / Published online: 10 August 2021

(C) The Author(s) 2021

\begin{abstract}
The capacity to assess invasion risk from potential crop pests before invasion of new regions globally would be invaluable, but this requires the ability to predict accurately their potential geographic range and relative abundance in novel areas. This may be unachievable using de facto standard correlative methods as shown for the South American tomato pinworm Tuta absoluta, a serious insect pest of tomato native to South America. Its global invasive potential was not identified until after rapid invasion of Europe,
\end{abstract}

Supplementary Information The online version contains supplementary material available at https://doi.org/10.1007/ s10530-021-02613-5.

\section{Ponti $(\bowtie)$}

Agenzia nazionale per le nuove tecnologie, l'energia e lo sviluppo economico sostenibile (ENEA), Centro Ricerche Casaccia, Via Anguillarese 301, 00123 Roma, Italy e-mail: luigi.ponti@enea.it

L. Ponti · A. P. Gutierrez

Center for the Analysis of Sustainable Agricultural Systems Global (CASAS Global), Kensington,

CA 94707, USA

\section{A. P. Gutierrez}

Ecosystem Science, College of Natural Resources, University of California, Berkeley, CA 94720, USA

M. R. de Campos · N. Desneux

Université Côte d'Azur, INRAE, CNRS, UMR-ISA, 06000 Nice, France followed by Africa and parts of Asia where it has become a major food security problem on solanaceous crops. Early prospective assessment of its potential range is possible using physiologically based demographic modeling that would have identified knowledge gaps in T. absoluta biology at low temperatures. Physiologically based demographic models (PBDMs) realistically capture the weather-driven biology in a mechanistic way allowing evaluation of invasive risk in novel areas and climes including climate change. PBDMs explain the biological bases for the geographic distribution, are generally applicable to species of any taxa, are not limited to terrestrial

\author{
A. Biondi \\ Department of Agriculture, Food and Environment, \\ University of Catania, Via Santa Sofia 100, Catania, Italy \\ M. Neteler \\ mundialis GmbH \& Co. KG, Kölnstrasse 99, 53111 Bonn, \\ Germany
}


ecosystems, and hence can be extended to support ecological risk modeling in aquatic ecosystems. PBDMs address a lack of unified general methods for assessing and managing invasive species that has limited invasion biology from becoming a more predictive science.

Keywords Physiologically based demographic models · Invasive species - Geographic distribution · Relative abundance $\cdot$ Prevention of biological invasions $\cdot$ Climate change

\section{Introduction}

Predicting the potential geographic distribution and relative abundance of invasive species prior to invasion is key to the assessment of risk and management (Bradshaw et al. 2016; Lenzner et al. 2019). A bellwether failure of pre-invasion assessment is the South American tomato pinworm Tuta absoluta (Meyrick) (Lepidoptera: Gelechiidae), a serious native insect pest of tomato in South America (Desneux et al. 2010). It was not identified as a serious threat by the European Union (EU), the USA, or other tomato-growing areas, until it invaded Spain in 2006, from where it spread rapidly across Europe, Africa, and Asia (Pratt et al. 2017; Biondi et al. 2018; Han et al. 2019). This oligophagous leaf miner and its primary tomato host are native to South America, specifically Peru where both originated (Blanca et al. 2015; Biondi et al. 2018). The species was described from individuals collected in Huancayo in the central Andean highlands of Peru (Biondi et al. 2018), a location at $-12.065^{\circ}$ latitude, $-75.205^{\circ}$ longitude, and $3245 \mathrm{~m}$ altitude with a cold semi-arid steppe climate. The pest develops on solanaceous species, the most suitable ones being tomato, potato, and European black nightshade (Solanum nigrum) (Biondi et al. 2018), but it is also recorded from other cultivated Solanaceae (e.g., eggplant) (Cherif et al. 2019; Sylla et al. 2019). Tomato is widely grown in the western Palearctic (Europe and Mediterranean Basin) and North America (Supplementary Information, SI, Figs. S1 and S2).

Given its host range of agriculturally important crops and its status as a key pest of tomato in South America, it is surprising that large tomato producing entities with well-organized plant quarantine infrastructure such as the EU and the USA failed to consider the invasion risk the moth posed (Biondi et al. 2018; Desneux et al. 2010). In 2006, moths from a single Chilean population invaded Spain (Guillemaud et al. 2015), and in ten years expanded its distribution to $60 \%$ of the global tomato growing area from northern Europe to South Africa, and from West Africa to South Asia. This area includes six of ten top tomato-growing countries in the Palearctic (i.e., India, Turkey, Egypt, Iran, Italy, Spain). The moth has recently invaded China (the top producer) (Zhang et al. 2019; Li et al. 2020) but not the USA (fourth) and Mexico (ninth) (Biondi and Desneux 2019) although it is present in Haiti (Verheggen and Fontus 2019). To understand this invasion, we need to know why this species was able switch from being a local pest of tomato in South America to become a global food security threat in climes beyond its recorded distribution. Accurate risk analysis of T. absoluta before 2006 would have triggered global quarantine measures, preventing its unprecedented rapid invasion.

Three post hoc attempts were made between 2010 and 2019 to estimate its potential global distribution as affected by extant weather (Desneux et al. 2010; Han et al. 2019) and climate change (Santana et al. 2019) using the ecological niche modeling software CLIMEX (Sutherst and Maywald 1985). CLIMEX and other correlative methods are de facto standards that use presence-absence data to find climatic correlates as indices of favorability to predict the prospective distribution of ectotherm species (Elith 2017). Such studies may not contain records from the full climatic range of the species, and further lack mechanistic biological underpinnings, hence as occurred for $T$. absoluta may fail to predict and explain the full invasive range in novel areas such as the Palearctic.

Here, a mechanistic physiologically-based demographic model (PBDM) (Gutierrez 1996; Ponti et al. $2015 \mathrm{a}, \mathrm{b}$ ) that captures the weather-driven biology of the moth is developed to explain and predict prospectively its invasiveness in the western Palearctic and in uninvaded areas such as the USA and Mexico under extant and climate change scenarios. 


\section{Materials and methods}

The PBDM for T. absoluta is mathematically the same as the model of the daily dynamics developed for the light brown apple moth Epiphyas postvittana (Walk.) (Lepidoptera: Tortricidae) (Gutierrez et al. 2010), and consists of two components:

- A general age-structured distributed maturation time model of the daily dynamics of the moth (Eq. 1); and

- Weather-driven biodemographic functions (BDFs) that parameterize the age-structured biology $T$. absoluta, and capture the time varying effects of temperature and relative humidity on vital rates (sensu Hughes and Gilbert 1968; Gutierrez 1992) (see Fig. 1).
Biological models will always be incomplete, and the field and laboratory data used to parameterize them may have differences due to experimental methods and other factors. Hence the use of data from the literature to parameterize the BDFs must be assessed for internal consistency (data outliers) and for consistency with other data sets for the same factor (see below). Well parameterized PBDMs have given robust predictions about the time-place varying densities of species, and in the aggregate across a lattice of locations with different weather; results that are mapped to predict their geographic distribution and relative abundance (e.g., Gutierrez and Ponti 2013). In sequence we review the dynamics model and the imbedded biodemographic functions that capture the weather-driven biology of T. absoluta.
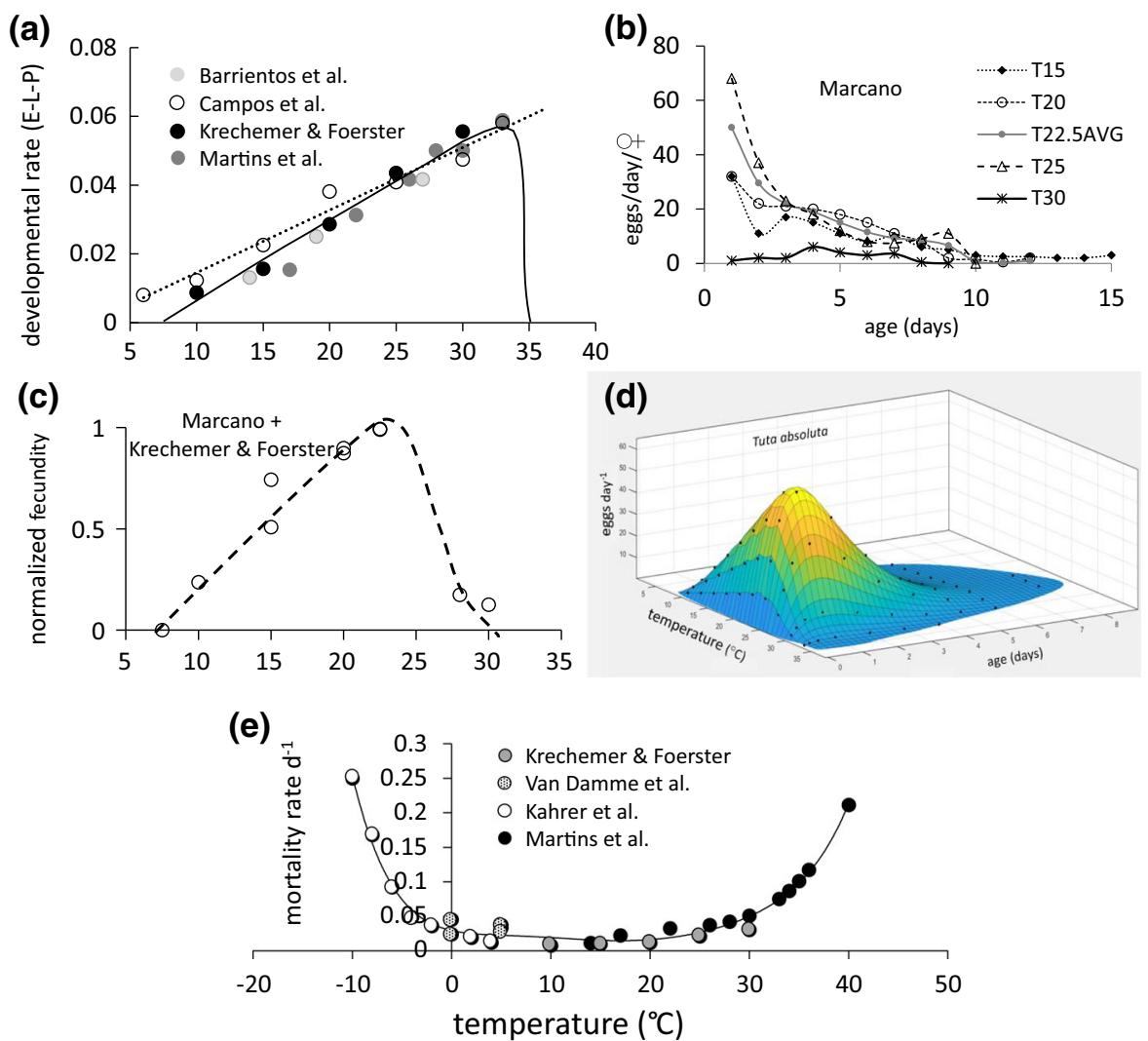

Fig. 1 Thermal biology of Tuta absoluta: development, reproduction, and mortality as a function of temperature. a Developmental rate of the egg-pupal stages as a function of temperature (data from Barrientos et al. 1998; Krechemer and Foerster 2015; Martins et al. 2016; Campos et al. 2020). b Agespecific fecundity (data from Marcano 1995). c Normalized gross fecundity as a function of temperature (data from Marcano
1995; Krechemer and Foerster 2015). d Oviposition per female as a function of age and temperature (Eq. 8). e Temperaturedependent mortality (data from Van Damme et al. 2015; Krechemer and Foerster 2015; Martins et al. 2016; Kahrer et al. 2019) with the line indicating the fitted polynomial function used in the model 
The dynamics model

Cohorts of individuals in the population experience different weather and hence have different patterns of time-varying means and variance for developmental times, and this is easily modeled using a weatherdriven distributed maturation time model (Eq. 1) based on Manetsch (1976) and Vansickle (1977). We note that other dynamics models could also be used (see Gutierrez 1996; Di Cola et al. 1999; Buffoni and Pasquali 2007). The four life stages (left superscript $\mathrm{s}=\mathrm{E}, \mathrm{L}, \mathrm{P}, \mathrm{A}$ for the egg, larval, pupal, and adult stages respectively) are modeled by a system of ${ }^{s} k$ equations (Eq. 1) that describes the dynamics of the $i$ th of ${ }^{s} k$ age class. The distribution of developmental times in the absence of mortality is described by an Erlang distribution with parameter $k$ equal to the number of within stage age classes required to approximate the observed mean $\left({ }^{\mathrm{s}} \Delta\right)$ and variance ( $\mathrm{s}$ var) of developmental time of cohort members. Following the notation of Di Cola et al. (1999, p. 523), the $i$ th age class of stage $s$ is modeled as follows:

$\frac{d^{s} N_{i}}{d t}=\frac{{ }^{s} k \cdot{ }^{s} \Delta_{x}}{{ }^{s} \Delta}\left[{ }^{s} N_{i-1}(t)-{ }^{s} N_{i}(t)\right]-{ }^{s} \mu_{i}(t)^{s} N_{i}(t)$

In terms of flux, ${ }^{s} n_{i}(t)={ }^{s} N_{i}(t){ }^{s} v_{i}(t)$ where ${ }^{s} v_{i}(t)=\frac{s k}{s \Delta} \Delta_{x}(t)$, and

$\frac{d}{d t}\left[\frac{{ }^{s} \Delta}{{ }^{s} k} n_{i}(t)\right]={ }^{s} n_{i-1}(t)-{ }^{s} n_{i}(t)-{ }^{s} \mu_{i}(t){ }^{s} n_{i}(t) \frac{{ }^{s} \Delta}{{ }^{s} k}$

Note that new eggs flow into the first age class of the egg stage with the outflow from the $k$ th age class of the previous stage flowing into the first age class of the next stage (e.g., egg to larval, etc.). Ignoring the stage superscript, $N_{i}$ is the number density of the $i$ th age class, $d t$ is the change in time (e.g., a day), $\Delta$ is the expected mean stage developmental time, $\Delta_{x}$ is the daily increment of physiological age in degree days for all life stages that varies with temperature, and $\mu_{i}(\mathrm{t})$ is the proportional age-specific net loss rate as modified by temperature, age, net migration, and mortality due to natural enemies. The Euler integration scheme implemented for the discretized model is found in Gutierrez (1996, page 157).
Biodemographic functions

\section{Developmental rate}

The time step in our PBDM is a day of variable length in physiological time units. Shorter time steps could be used, but the adage holds that "one needn't measure something with a micrometer if one must cut it with an axe".

Development may also be modified by nutrition, dormancy, and other factors, but are not included in the model (Gutierrez 1992, 1996). The developmental rate per day at temperature $T$ is the reciprocal of developmental time in days $(d): r(T)=1 / d(T)$. Developmental times and rates at different temperatures (Fig. 1a) are for the total egg, larval, and pupal period $\left(\Delta_{E-P}\right)$. We could have modeled the developmental rate of each life stage separately (Marchioro et al. 2017), but accurate data for the leaf miner is difficult to obtain, and daily observations for life stages with shorter developmental times tend to have larger error rates. The data for the E-P period from different studies in the literature are largely consistent (Fig. 1a), and a non-linear model (Eq. 3) was iteratively fit to the data (Gutierrez and Ponti 2013) $\left(\chi^{2}=0.000312\right.$, reduced $\chi^{2}=0.000015$; computed using the lmfit Python package version 1.0.2, Newville et al. 2014).

${ }^{E-P} r(T(t))=\frac{a\left(T(t)-\theta_{L}\right)}{1+b^{\left(T(t)-\theta_{U}\right)}}=\frac{0.0024(T(t)-7.9)}{1+3.95^{(T(t)-34.95)}}$

The parameters of Eq. 3 are defined as follows: $T(t)$ is the mean daily temperature on day $t$, the coefficient $a=0.0024$ is the initial slope of the function (Bieri et al. 1983), $\theta_{L}=7.9{ }^{\circ} \mathrm{C}$ is the lower thermal threshold for development, $\theta_{U}=34.95{ }^{\circ} \mathrm{C}$ is approximately the highest temperature before the function begins to decline to zero, and $b=3.95$ is a constant. A similar function was proposed by Briére et al. (1999). We assume that $\theta_{L}$ is the same for all life stages.

Temperatures experienced by $T$. absoluta by the egg and adult stages are ambient, while larvae and pupae in leaf mines experience temperatures that differ from ambient, and we must account for the difference. For example, Baumgärtner and Severini (1987) developed a microenvironment simulator based on a daily balance equation of a wet body to estimate temperatures experienced by apple leaf miner 
moth (Phyllonorycter blancardella) larvae and pupae. Pincebourde and Casas (2006) developed a heat budget model for $P$. blancardella, and found that mine temperatures were higher than leaf surface temperatures and varied with irradiance. Their heat budget model with irradiance levels ranging from 0 to $1300 \mu \mathrm{mol} \mathrm{m} \mathrm{m}^{-2} \mathrm{~s}^{-1}$, temperatures ranging from 11 to $36{ }^{\circ} \mathrm{C}$, and relative humidity ranging from 20 to $90 \%$, enabled them to map changes in leaf mine temperatures. Unfortunately, due to lack of appropriate data, we were unable to implement their heat budget model explicitly in our PBDM, but we could estimate the effects of temperature and irradiance from their simulation data (i.e., Fig. 8 in Pincebourde and Casas 2006). A conversion of $1 \mathrm{~W} \mathrm{~m}^{-2} \approx 4.6 \mu \mathrm{mol} \mathrm{m} \mathrm{m}^{-2}$ $\mathrm{s}^{-1}$ was made to accommodate the units in our weather data (Sager and McFarlane 1997), and a linear multiple regression model was fit to the data to estimate the change in temperature in mines relative to ambient $\left(\Delta T_{\mathrm{m}}\right)$ at time $t$, temperature $T$ (i.e., ${ }^{\circ} \mathrm{C}$ ), relative humidity $(0<R H<1)$, and irradiance $\left(\mathrm{Wm}^{-2}\right)$ :

$0 \leq \Delta T_{m}=-1.574-0.07 T+1.42 R H+0.035 W^{-2}$ $R^{2}=0.99$

The daily mean temperature $(T)$ experienced by larvae and pupae in leaf mines is

$\widehat{T}(t)=T(t)+\Delta T_{m}(t)$,

and substituted for $T$ in Eq. 3. Increases in leaf surface temperatures relative to mine temperatures across all irradiation values are $\sim 0.65 \Delta \mathrm{T}_{\mathrm{m}}$.

Our PBDM is a discrete time model and daily increments of degree days $\left(\Delta_{x}\right)$ are computed as the proportions of the egg to new adult developmental time completed during day $t$ at temperature $T$. Using the stage notation in Eq. 1, the thermal constant for substage ${ }^{s} \Delta$ in degree days ( $d d$ above $\theta_{L}$ ) is computed in the linear range of favorable temperatures as ${ }^{s} \Delta=$ ${ }^{s} d(T)\left(T-\theta_{L}\right)$. Specifically, average ${ }^{\mathrm{E}} \Delta$ for the egg stage is $82.3 d d,{ }^{\mathrm{L}} \Delta=218.8 d d,{ }^{\mathrm{P}} \Delta=122.9 d d$, and ${ }^{\mathrm{A}} \Delta=189.2 d d$ is adult female longevity. The preoviposition period under nonlimiting host conditions is approximately 30.4dd (Bentancourt et al. 1996; Krechemer and Foerster 2015, 2017). A life stages completes development when $\sum \Delta_{x}(\mathrm{t})={ }^{\mathrm{s}} \Delta$.

\section{Oviposition}

Oviposition occurs on the leaf surface and is assumed to be at ambient temperatures. Per capita oviposition was estimated by several authors, but we used the data from Marcano (1995) (Fig. 1b) to estimate the maximum age-dependent oviposition profile at the optimum temperature of $25{ }^{\circ} \mathrm{C}$ that was fit with the leftbiased Bieri et al. (1983) function, where adult age is in days $(d)$.

$F\left(d, T_{o p t}=25^{o} C\right)=160 d / 2.6^{d}$

At $T_{o p t}, \Delta_{\mathrm{x}}$ is $17.1 d d$ per day, and hence $d$ in Eq. 6 can be converted to adult physiological age (i.e., days $\times 17.1 d d)$. Reversing the process, we can estimate the number of adults $\left({ }^{\mathrm{A}} \mathrm{N}(\mathrm{t}, \mathrm{d})\right)$ of age $d$ at time $t$. Fecundity also varies with temperatures (Fig. 1b), and while studies report different values, when normalized within each data set, a consistent relationship with temperatures arises. Hence, to correct Eq. 6 for the effects of temperature, we model the normalized data from Marcano (1995) and Krechemer and Foerster (2015) with a concave right-skewed function (Eq. 7) (Fig. 1c)

$0 \leq \phi_{f e c}(T(t))=\frac{0.0665(T(t)-7.9)}{1+2.2^{(T(t)-27.5)}} \leq 1$

where $7.9{ }^{\circ} \mathrm{C}$ is the lower thermal threshold for oviposition and $\sim 27.5^{\circ} \mathrm{C}$ is a fitted constant where the oviposition rate begins to decline to zero at $\sim$ $30{ }^{\circ} \mathrm{C}$. From this, we generate a three-dimensional fecundity function on age and temperature (Fig. 1d). Note the lower threshold for oviposition is the same as for development, but the upper threshold is $\sim 3{ }^{\circ} \mathrm{C}$ lower. Thus, the number of eggs (E) deposited by the population at time $t$ at temperature $T$ with assumed sex ratio $s r=0.5$ is

$E(T(t))=\operatorname{sr} \phi_{f e c}(T(t)) \sum_{d=1}^{d_{\max }} F\left(d, T_{o p t}\right)^{A} N(t)$

As indicated, new eggs enter the first age class of the egg population dynamics model (Eq. 1).

\section{Mortality}

There are many sources of mortality, but in the model, we include only the major effects of temperature and a 
composite mortality function for predation, host finding, and other biotic factors.

Temperature-dependent mortality Studies under simulated greenhouse conditions (Cuthbertson et al. 2013) and in the laboratory (Bentancourt et al. 1996; Barrientos et al. 1998; Van Damme et al. 2015; Krechemer and Foerster 2015; Martins et al. 2016; Özgökçe et al. 2016) estimated temperature-dependent mortality rates. However, only Kahrer (2015) and Kahrer et al. (2019) estimated the degree of cold hardening that can occur in the moth allowing it to survive at temperatures well below $7.9^{\circ} \mathrm{C}$; conditions that normally occur to varying degrees during the fallwinter-spring period in different parts of T. absoluta's expanding range. Hence, the effects of daily temperature on daily mortality rates across all temperatures $\left(\mu_{T}(\mathrm{~T})\right)$ were estimated from literature data (Van Damme et al. 2015; Krechemer and Foerster 2015; Martins et al. 2016; Kahrer et al. 2019), and were fit with a polynomial model with biological limits (Eq. 9, $R^{2}>0.96$ ) (see Fig. 1e). A simpler function could have been used, but we chose accuracy of fit rather than elegance with the extra decimal places given for reproducibility by others. Note that ambient temperatures are used in Eq. 9 for the egg and adult stages, while estimated mine temperatures (i.e., $\mathrm{T}=\widehat{T}$ ) are used for the larval and pupal stages.

$$
\begin{aligned}
0<\mu_{T}(T) & =-0.0000000154 T^{5}+0.0000018596 T^{4} \\
& -0.0000684161 T^{3} \\
& +0.0009628846 T^{2}-0.0043019458 T \\
& +0.0243091352 \leq 1
\end{aligned}
$$

Other sources of mortality Miranda et al. (1998) conducted field life table analyses in Brazil to estimate survivorship of T. absoluta immature stages, but the results are time and place specific. A type II model (Eq. 10, Gutierrez 1996) is used to capture the effects of composite sources of predation/parasitism mortality per $d d$ at temperature $T$ (i.e., $\Delta_{x}(t)$ ), and density of each stage $\left({ }^{\mathrm{s}} \mathrm{N}(\mathrm{t})\right)$, and to keep the dynamics within reasonable bounds (Eq. 10).

$0<{ }^{s} \widehat{\mu}(t)=1-e^{-c \Delta_{x}(t)^{s} N(t)}$

where $c=0.00025$ is the assumed apparency rate of moth stages per $d d$.
To estimate the joint mortality, we write the interaction as survivorship terms for age $i$ as $1-$ ${ }^{s} \mu_{i}(t)=\left(1-{ }^{s} \mu_{T}(T(t)) \cdot\left(1-{ }^{s} \widehat{\mu}(t)\right)\right.$ and then solve for $\quad{ }^{s} \mu_{i}(t)={ }^{s} \mu_{T}(T(t))+{ }^{s} \widehat{\mu}(t)-{ }^{s} \mu_{T}(T(t))^{s} \widehat{\mu}(t) \quad$ in Eq. 1.

Weather data

Daily weather data for maximum and minimum temperature, rainfall and solar radiation $(\mathrm{MJ} /$ $\mathrm{m}^{2} / \mathrm{day}^{2}$ ) were used to drive PBDM simulations. Weather for present climate simulations was from AgMERRA, the global baseline forcing dataset of the Agricultural Model Inter-comparison and Improvement Project (AgMIP, http://www.agmip.org/) (Ruane et al. 2015) (https://data.giss.nasa.gov/impacts/ agmipcf/). AgMERRA is a reanalysis of weather observations (Rienecker et al. 2011) combined with observational datasets from in situ observational networks and satellites (Ruane et al. 2015). Daily AgMERRA weather at $\sim 25 \mathrm{~km}$ spatial resolution was used for the period 1 January 1990 to 31 December 2010 for 17,791 lattice cells across the Euro-Mediterranean region and 15,843 for the USA and Mexico. The climate data summary for Huancayo, Peru is from CLIMATE-DATA.ORG (ClimateData.org 2019).

Daily weather for climate change simulations in the Euro-Mediterranean region was from the A1B regional climate change scenario with $\sim 30 \mathrm{~km}$ resolution for the Euro-Mediterranean region developed by Dell'Aquila et al. (2012) using the regional climate model PROTHEUS (Artale et al. 2010) to refine coarser ( $\sim 200 \mathrm{~km}$ resolution) global climate simulations (http://www.nextdataproject.it/?q=en/content/ regional-climate-simulations-enea). PROTHEUS is a coupled atmosphere-ocean regional model that allows simulation of local extremes of weather via the inclusion of a fine-scale representation of topography and the influence of the Mediterranean Sea (Artale et al. 2010). The A1B scenario is towards the middle of the IPCC (IPCC 2014) range of greenhouse gas (GHG) forcing scenarios (Giorgi and $\mathrm{Bi}$ 2005), and the uncertainty associated with climate model predictions forced using the A1B scenario is low for the Mediterranean region relative to the rest of the globe (Gualdi et al. 2013). Based on this downscaled climate change scenario, a daily weather dataset was 
developed for the period 1 January 2040 to 31 December 2050 for 10,598 lattice cells in the EuroMediterranean region.

Daily climate change simulations for the USA and Mexico were driven by the NASA Earth Exchange Global Daily Downscaled Projections (NEX-GDDP) dataset (Thrasher et al. 2012) at $\sim 25 \mathrm{~km}$ resolution, derived from global climate simulations (Taylor et al. 2012) of the Max Planck Institute Earth System Model low resolution (MPI-ESM-LR) model (https://www. nccs.nasa.gov/services/data-collections/land-basedproducts/nex-gddp). Global MPI-ESM-LR climate simulations were forced by the Representative Concentration Pathway 8.5 (RCP 8.5) scenario (Riahi et al. 2011) that corresponds to a range of warming similar to A1B (Rogelj et al. 2012). Sheffield et al. (2013) evaluated historical simulations of North American climate using continental metrics of bias relative to weather observations and showed that MPI-ESM-LR is the top ranked among the core set of 17 global climate models considered. Based on this downscaled climate change scenario, a daily weather dataset was developed for the period 1 January 2045-31 December 2075 for 20,355 lattice cells in the USA and Mexico.

The downscaled climate change scenarios used in this study include high-resolution daily weather data designed for assessing climate change impacts on processes that are sensitive to fine-scale climate and local topography, such as biological processes of poikilotherm organisms like T. absoluta and other invasive pest insects. Downscaling (i.e., increasing the spatial resolution) of global climate model output addresses two primary limitations: the relatively coarse spatial resolution of global climate models (e.g., hundreds of $\mathrm{km}$ ) and their statistical bias when compared with observations (Thrasher et al. 2012). We used climate scenarios that were tested in previous PBDM analyses (Ponti et al. 2014; Gutierrez et al. 2019) in an effort to contribute towards providing credible information on regional climate changes, impacts, and risks for stakeholders and policy-makers (Eyring et al. 2019).
PBDM simulation and GIS analysis

The PBDM for T. absoluta was run continuously across all lattice cells for the specified periods, with no migration occurring between lattice cells. The starting day for all runs was 1 January of the first year with an initial nominal density of $0.1 \mathrm{~m}^{-2}$ for each life stage at all locations. While the model predicts the daily density of all stages of $T$. absoluta, only cumulative pupal density per square meter per year was used as the main metric (indices) of favorability. The simulation data were geo-referenced and written to batch files by year for mapping and analysis. Because the model must equilibrate, the first year's results for all simulation runs were not used to compute lattice cell averages, standard deviations, and coefficient of variations $(\%)$.

The open source geographic information system (GIS) GRASS (Neteler et al. 2012) originally developed by the United States Army Corps of Engineers was used for geospatial data management, analysis, and mapping using bicubic spline interpolation on a $3-\mathrm{km}$ raster grid. The version of GRASS used is maintained and further developed by the GRASS Development Team (2020) (see http://grass.osgeo. org). Further processing and plotting of raster layers generated by GRASS were done using R (R Core Team 2020) with packages raster (Hijmans 2020) and ggplot2 (Wickham 2016).

Geographic information layers for climate-limited tomato distribution are from the Global Agro-ecological Zones (GAEZ v3.0) dataset (IIASA and FAO 2012) (http://www.fao.org/nr/gaez/en/). We used two GAEZ temperature-constrained potential distribution maps for tomato (irrigated, with intermediate input level, and with a 105 days growth cycle, for average climate 1961-1990): the distribution of temperatesubtropical tomato cultivars and the distribution of tropical-subtropical tomato cultivars in open field conditions. We combined the two distributions, including only the highest favorability class in the maps. The combined tomato distribution (SI, Figs. S1 and S2) was used in this study when mapping the geographic distribution of T. absoluta to correct for the distribution of tomato. Data on global tomato production are from FAOSTAT (see http://faostat.fao. org/).

Using GRASS GIS, CLIMEX maps and data from other studies were digitized from PDFs of published 
papers, orthorectified, and converted to the Albers Equal Area projection used in this study.

\section{Results}

Modeling T. absoluta dynamics inside leaf mines

During the year, weather in temperate areas may vary from hot summers to cold winters. Under either extreme, conditions may prove unfavorable for the development, reproduction, and survival of moth life stages. Simulated pupal dynamics as affected by weather are used as a metric of T. absoluta abundance and as a measure of location favorability.

We use weather data for Sacramento, California (USA), an area where field tomato is widely grown, to illustrate the interacting effects of temperature and irradiance on Tuta dynamics. Summers in Sacramento are hot and winters may be cool to cold with occasional frosts. The 2000-2010 simulation for Sacramento in Fig. 2 is shown as a detailed subset for 2009 and 2010 in Fig. 3. Using ambient temperatures, the seasonal dynamics of the moth $\left(\right.$ pupae $\mathrm{m}^{-2}$ ) in Sacramento are affected by high temperatures, while during the winter period, oviposition stops but low numbers of pupae survive $\left(<\right.$ one pupa $\mathrm{m}^{-2}$; Fig. 2a, solid line). However, if we include the effects of full irradiance on the outer margins of the canopy, the higher mine temperatures increase larval and pupal mortality during summer (not shown), driving pupal populations to near zero (Fig. 2a; shaded area). Tuta populations rebound only slightly with cooler fall weather, but pupal survival during the winter period is low.

However, in the field, adult moths select more favorable conditions within the canopy for oviposition and for the development of their progeny (Gomide et al. 2001; Torres et al. 2001; Cocco et al. 2015). Using Beer's Law with a light extinction coefficient of 0.8 and assuming a full canopy ( $\mathrm{LAI}=4.5), 0.5$ light penetration would occur at $\sim 19.15 \%$ of canopy depth on fully expanded leaves. Hence, comparing the effects of ambient temperatures without the effect of irradiance and with 0.5 irradiance in the canopy (Fig. 2b), pupal dynamics of the two scenarios are nearly identical. Further, earlier appearance of pupae is predicted in spring at 0.5 irradiance compared to ambient. This is similar to that found by Baumgärtner and Severini (1987) for the apple leaf miner at Chur, Switzerland, where changes in the microenvironment of mines influenced the emergence times, rates, and the duration of the flights with the magnitude dependent on local environmental conditions. This suggests tradeoffs occur between increases in developmental rates and temperature-dependent mortality. Variations of temperature and irradiance-driven dynamics occur throughout the moth's range, and hence for all georeferenced lattice cells in all runs of the model, we use 0.5 irradiance as a standard including the additional effects of relative humidity (see Eq. 3).

The daily weather and the simulated population dynamics for Sacramento in Fig. 3 illustrate some of the complexity of factors affecting the dynamics of $T$.
Fig. 2 Daily dynamics of $T$. absoluta inside tomato leaf mines as affected by solar radiation: a comparison of the effects of ambient temperature and full irradiance on mine temperatures, and b comparison of the effects of ambient temperature and 0.5 irradiance on the dynamics of the pupal stage

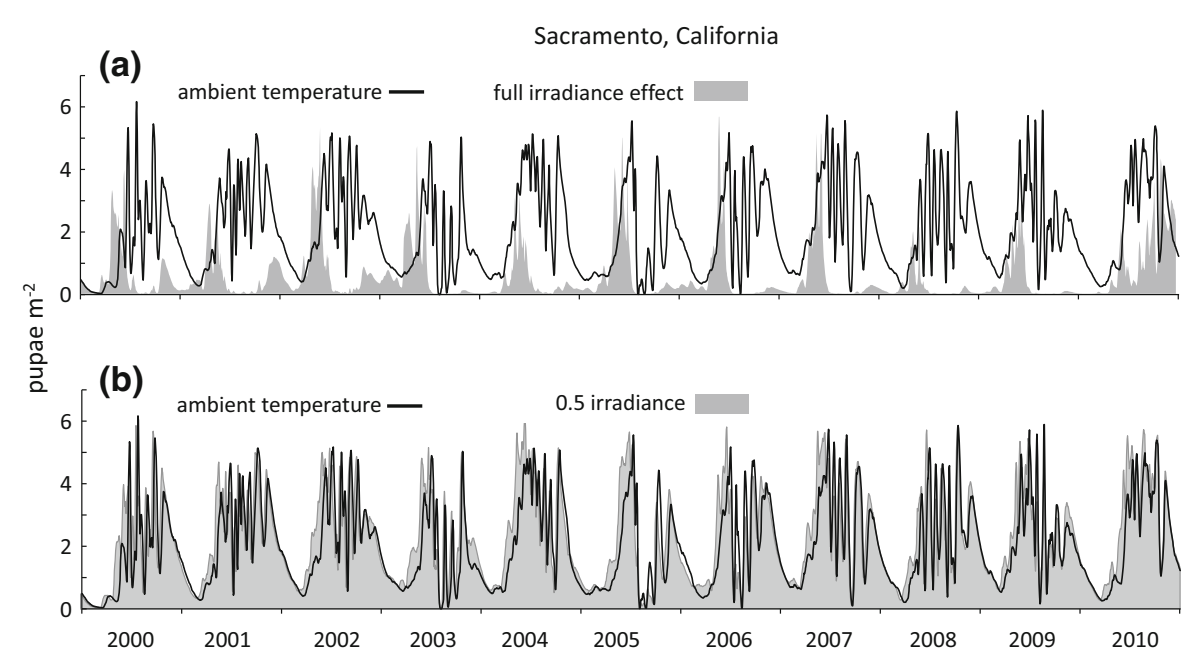




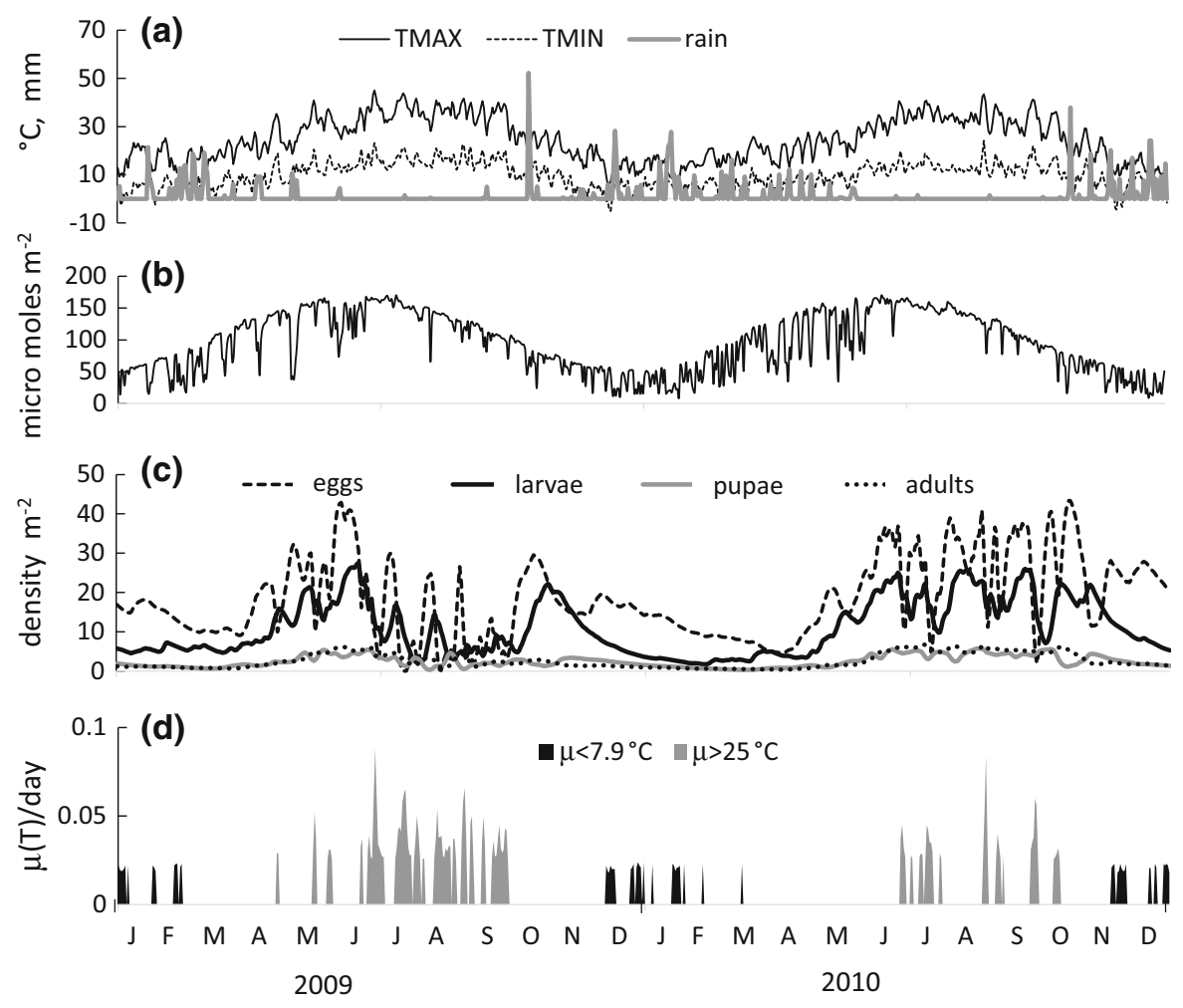

Fig. 3 Simulation of the daily dynamics of T. absoluta life stages during 2009 and 2010 in Sacramento, California (USA). a Daily maximum and minimum temperatures $\left({ }^{\circ} \mathrm{C}\right)$ and rainfall $(\mathrm{mm})$; b solar radiation in micro mole $\mathrm{m}^{-2} \mathrm{~s}^{-1} \mathrm{~d}^{-2}$; $\mathbf{c}$ the dynamics of $T$. absoluta life stages; and $\mathbf{d}$ the daily mortality rate

absoluta that occur in all of the $\sim 30,000$ lattice cells (see Sect. 2.3. Weather data). Figure $3 a$ and $b$ illustrate the maximum and minimum temperatures and solar radiation used to drive the model, but relative humidity is not illustrated. Figure $3 \mathrm{c}$ shows the dynamics of moth life stages as affected by weather (see Fig. 3d; Eq. 9). Mortality occurs due to cold temperatures below the lower thermal threshold (black line) and high temperatures above the optimum temperature for oviposition (gray line) (Fig. 3d; see Fig. 1e), but the mortality is not severe enough to limit invasion by the moth (see below Sect. 3.3).

Across the geographic landscape, each location (lattice cell) and year, weather would produce distinctive dynamical population dynamics, with the yearly total of pupae used as a metric of favorability for the moth.
(Eq. 9) of immature life stages below the developmental threshold temperature $\left(\mu_{<7.9{ }^{\circ} \mathrm{C}}\right.$, black) and similarly above $25{ }^{\circ} \mathrm{C}$ where reduced reproduction and increased mortality begin to occur $\left(\mu_{>25}{ }^{\circ} \mathrm{C}\right.$, grey, Fig. 1c, e)

Invasiveness in the Euro-Mediterranean region

Highest predicted populations of T. absoluta are in coastal areas of southern Spain and North Africa, with populations decreasing into colder areas of Europe (Fig. 4a, b, c; mean pupae, CV(\%), std respectively). The moth's distribution coincides with the known distribution of temperate and tropical field tomato (see SI, Fig. S1) grown under open field conditions in all areas except in hotter regions of North Africa and the Levant (Fig. 4d, e, f). The limits of distribution can be approximated by the annual cumulative daily mortality rates at low $\left(\mu_{<7.9^{\circ} \mathrm{C}}^{*}=\sum \mu_{<7.9^{\circ} \mathrm{C}}\right)$ and high $\left(\mu_{>25^{\circ} \mathrm{C}}^{*}=\sum \mu_{>25^{\circ} \mathrm{C}}\right)$ temperatures (Fig. $4 \mathrm{~g}, \mathrm{~h}$ respectively). Cold temperatures are limiting in temperate areas, with the geographic range of the moth limited above $\mu_{<7.9^{\circ} \mathrm{C}}^{*} \sim 3.5$ (see Fig. $4 \mathrm{~g}$ ). In contrast, high-temperature mortality is limiting in hot-dry 
no correction for tomato distribution
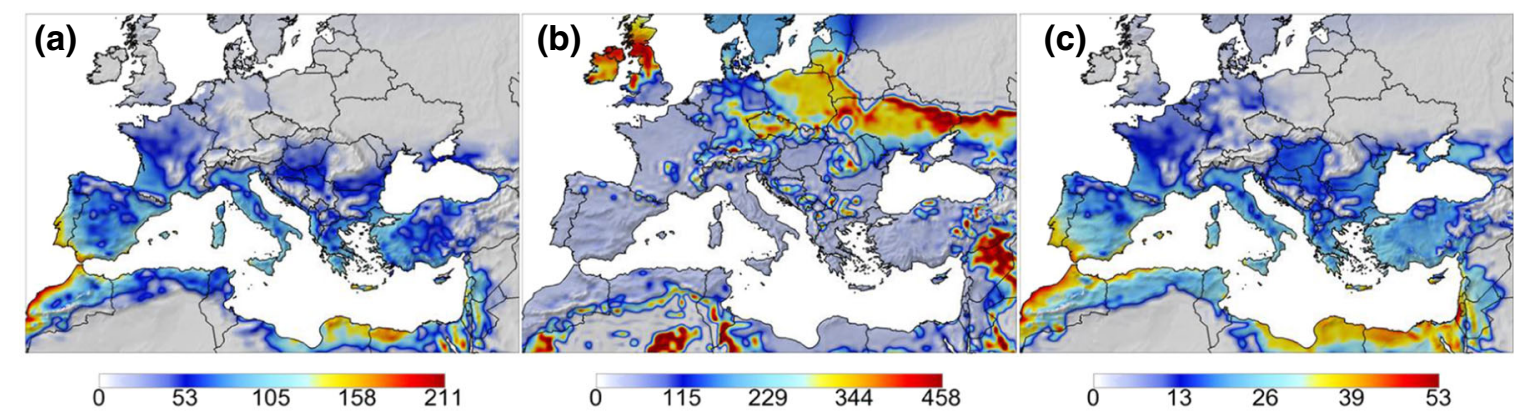

correction for tomato distribution
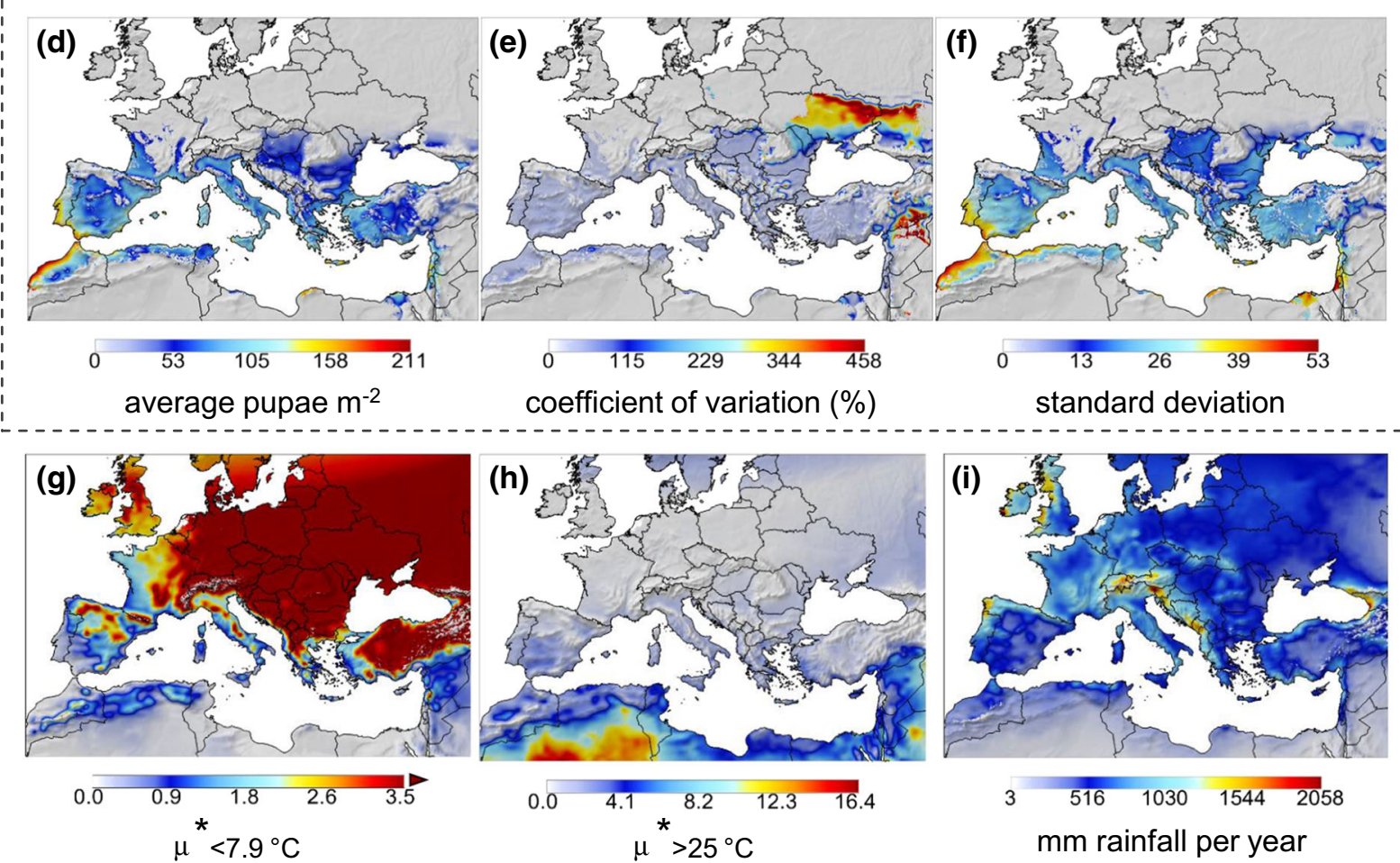

Fig. 4 Geographic distribution and relative abundance of $T$. absoluta in Europe and the Mediterranean Basin averaged for the period 1990-2010. The top row is not clipped for tomato distribution and shows a average cumulative number of pupae $\mathrm{m}^{-2}$ year ${ }^{-1} ; \mathbf{b}$ coefficient of variation as $\%$; and $\mathbf{c}$ the standard deviation. In the second row $\mathbf{d}, \mathbf{e}, \mathbf{f}$, the same variables are mapped as in (a), (b), and (c) but are clipped for the range of tomato (see SI, Fig. S1). The bottom row shows the cumulative yearly temperature mortality rates at low $\left(\mu_{<7.9^{\circ} \mathrm{C}}^{*}<3.5\right)(\mathbf{g})$ and at high temperatures $\left(\mu_{>25^{\circ} \mathrm{C}}^{*}\right)(\mathbf{h})$, and the total $\mathrm{mm}$ rainfall per year (i). The full data interval in $(\mathrm{g})$ is $[0.0,58.0]$ with values $>3.5$ mapped using the same darkest shade of red

$\mu_{<7.9^{\circ} \mathrm{C}}^{*}, \mu_{>25^{\circ} \mathrm{C}}^{*}$, and yearly rainfall totals $\left(\mathrm{mm}_{\text {rain }}\right)$ being the independent variables $(p<0.05)$ (Eq. 11). desert areas (i.e., North Africa and the Levant; Fig. 4h, i).

The data on untransformed average abundance were summarized using multiple linear regression with annual physiological time $\left(d d a>7.9^{\circ} \mathrm{C}\right)$, 


$$
\begin{aligned}
\text { pupae }^{-2}= & -42.558+0.029 d d a+0.023 m_{\text {rain }} \\
& -0.399 \mu_{<7.9^{\circ} \mathrm{C}}^{*}-6.616 \mu_{>25^{\circ} \mathrm{C}}^{*} \\
R^{2}= & 0.53, F=4,906, d f=17,783
\end{aligned}
$$

The computed $t$-values are 102.36 for $d d a>7.9^{\circ}$ $\mathrm{C}, 25.24$ for $\mathrm{mm}_{\text {rain }},-16.39$ for $\mu_{<7.9^{\circ} \mathrm{C}}^{*}$, and -89.06 for $\mu_{>25^{\circ} \mathrm{C}}^{*}$. The positive signs of the regression coefficients for $d d a$ and $m m_{\text {rain }}$ infer the positive effects of a longer favorable season, and the negative signs for cumulative low- and high-temperature mortality infer the limiting effects of cold and hot weather. The effect of high temperature is 16.5 -fold greater per unit mortality than that of low temperature. This is due primarily to cold hardiness, and a low upper threshold for reproduction $\left(\sim 30^{\circ} \mathrm{C}\right.$ ) (see Fig. 1). The summed low and high temperature mortality rates are qualitative metrics of favorability.

\section{Prospective invasiveness in USA and Mexico}

Tuta absoluta has not invaded North America, and hence our analysis is prospective of its potential geographic distribution and abundance. Highest populations are predicted in more temperate and tropical areas of Mexico, with moderate populations predicted in the southeastern USA, and in the Central Valley and southern near-coastal areas of California (Fig. 5a, b, c). The hotter dryer areas of North America are unfavorable, as are higher colder elevations and more northern reaches of the continent (Fig. 5a, b, c). The area of favorability for the moth is again quite similar to the distribution of temperate-tropical tomato cultivation (Fig. 5d vs. a). The limits to its geographic distribution are illustrated using the same constraints of average cumulative daily low $\left(\mu_{<7.9^{\circ} \mathrm{C}}^{*}<3.5\right.$; Fig. 5e) and high $\left(\mu_{>25^{\circ} \mathrm{C}}^{*}\right.$; Fig. 5f) temperature mortality rates found for the Euro-Mediterranean region. Absent irrigation, rainfall is also limiting in hot-dry areas of southwestern USA and Mexico (Fig. 5g). Note that in southern Texas and adjacent areas of Mexico, high temperature effects on mortality and reproduction are limiting despite abundant rainfall (see Fig. 5d and compare Fig. 5f vs. Fig. 5g).
Geographic distribution with climate warming

In Europe, under climate warming as estimated by climate models, the moth's distribution expands considerably northward and eastward to Eurasia (Fig. 6a) as seen by the recession of the $\mu_{<7.9^{\circ} \mathrm{C}}^{*} \sim 3.5$ boundary (Fig. $6 \mathrm{~b}$ vs. Fig. $4 \mathrm{~g}$ ), while in southern reaches of North Africa and the Levant, the area of favorability shrinks due to high temperatures $\left(\mu_{>25^{\circ} \mathrm{C}}^{*}\right.$; Fig. 6c vs. Fig. 4h).

In the USA and Mexico, the area of favorability shrinks profoundly in the southeastern USA and northern Mexico (Fig. 6d vs. Fig. 5a). The $\mu_{<7.9^{\circ} \mathrm{C}}^{*} \sim 3.5$ boundary recedes northward (Fig. $6 \mathrm{e}$ vs. Fig. 5e), while the cumulative high-temperature mortality rates increase in the desert areas of the southwestern USA and northwestern Mexico, and in the southeastern USA including Texas and eastern areas of Mexico including the Yucatan Peninsula (Fig. $6 f$ vs. Fig. 5f). Areas of favorability increase in higher elevations of the western US states.

\section{Discussion}

Before invading the Euro-Mediterranean region, $T$. absoluta was not a regulated quarantine pest, and tomato imports were not inspected for this pest at international borders in the EU and USA (Biondi et al. 2018). This occurred despite its known range expansion in South America and severe pest status on tomato in areas of Brazil having warm climates similar to Mediterranean coastal areas that were quickly invaded after it was first recorded in Spain (Desneux et al. 2010). Most Brazilian tomato is grown in three areas (Melo 1992): the Northeast with semi-arid climate (da Silva et al. 2005); the Southeast with tropical climate (Melo 1992); and the Center-West with Cerrado humid subtropical climate (Alvares et al. 2013). Temperatures in these areas of Brazil are on average $8-10{ }^{\circ} \mathrm{C}$ warmer than the cold semi-arid climate of the Andean highlands (Biondi et al. 2018).

But how best to examine T. absoluta biology in determining its geographic range and relative abundance was an open critical question. Based on records from these warm areas, its establishment at higher latitudes in Europe was considered unlikely (Desneux et al. 2010), but ultimately proved wrong. Among the 
no correction for tomato distribution
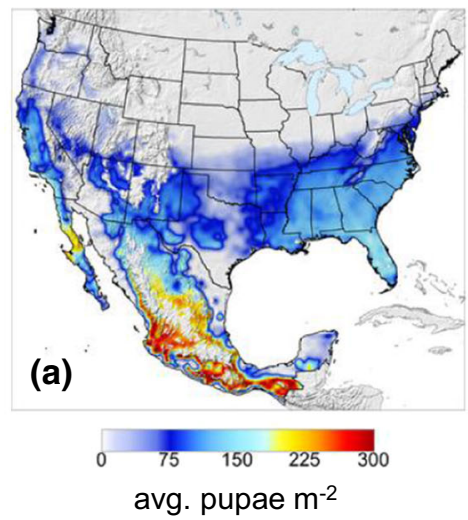

(b)

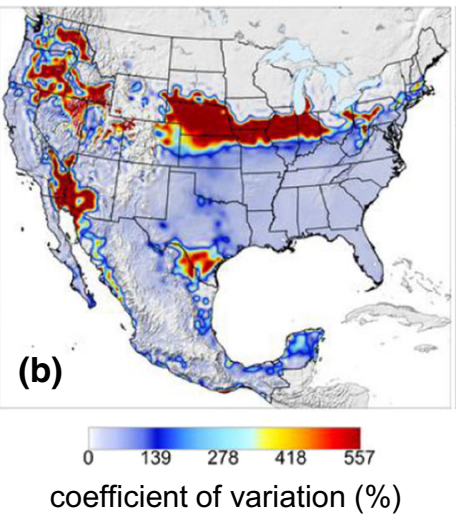

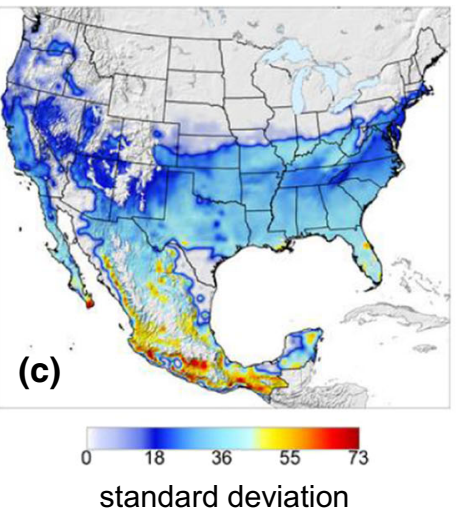

standard deviation

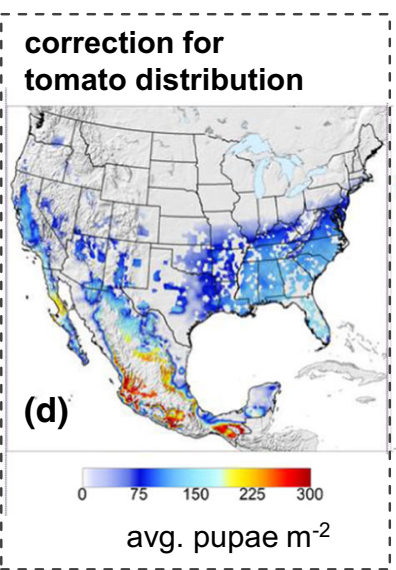

Fig. 5 Geographic distribution and relative abundance of $T$. absoluta in the USA and Mexico averaged for the period 19902010. The top row shows: a average cumulative number of pupae $\mathrm{m}^{-2}$ year $^{-1}$, b coefficient of variation as $\%$, and $\mathbf{c}$ standard deviation. The bottom row shows: $\mathbf{d}$ average cumulative yearly density of pupae as in (a) but clipped for tomato

approaches used to predict the moth's invasiveness were cellular automata that posited the importance of relative humidity and host plant distribution (Guimapi et al. 2016), and the widely used correlative environmental niche model (ENM) software CLIMEX. The CLIMEX software predicts the potential range of the moth using monthly averaged climatic correlates of occurrence in its known range (Desneux et al. 2010; Santana et al. 2019), and hence predictions are influenced by the distribution of these records (Elith 2017). The roots of CLIMEX are the early studies of Fitzpatrick and Nix (1970) who developed growth indices to estimate the climatic limits of Australian grasslands, and Gutierrez et al. (1974) and Gutierrez and Yaninek (1983) who used growth index models to
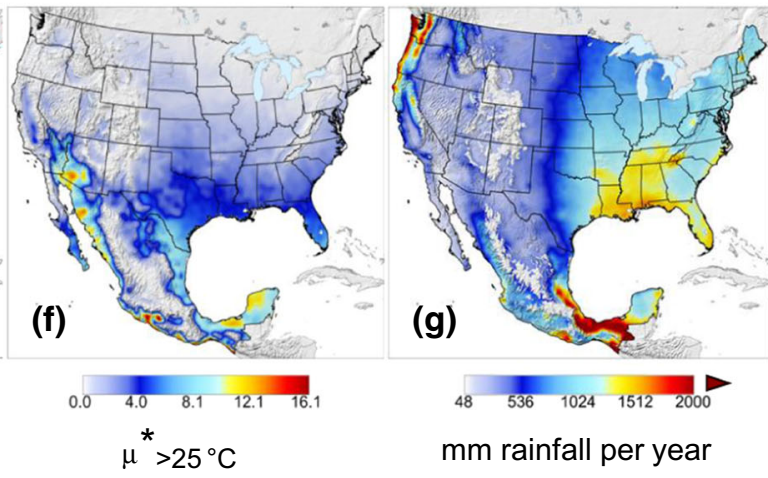

$\mathrm{mm}$ rainfall per year

distribution; e average yearly cumulative mortality rates for low temperatures clipped to $\mu_{<7.9^{\circ} \mathrm{C}}^{*} \leq 3.5$ (values $>3.5$ in dark red); $\mathbf{f}$ average yearly cumulative daily mortality rates for high temperatures $\left(\mu_{>25^{\circ} \mathrm{C}}^{*}\right)$; and $\mathbf{g}$ average annual rainfall $(\mathrm{mm})$

capture the climatic limits of aphids in southeastern Australia. Elements of these initial studies (i.e., growth indices) are found in PBDMs (Gutierrez 1996).

Three CLIMEX-based assessments of T. absoluta potential range were made based on available thermal development data (Desneux et al. 2010; Santana et al. 2019; Han et al. 2019). At the onset of global invasion in 2006, data on the thermal biology of T. absoluta were available only in the range of favorable temperatures above $12{ }^{\circ} \mathrm{C}$, with data below $12{ }^{\circ} \mathrm{C}$ reported starting in 2015, after invasion of central Europe occurred (Desneux et al. 2010) when its overwintering potential became evident (Van Damme et al. 2015). In 2010, the first CLIMEX analysis (Desneux et al. 2010) projected that only coastal southern Europe would be 

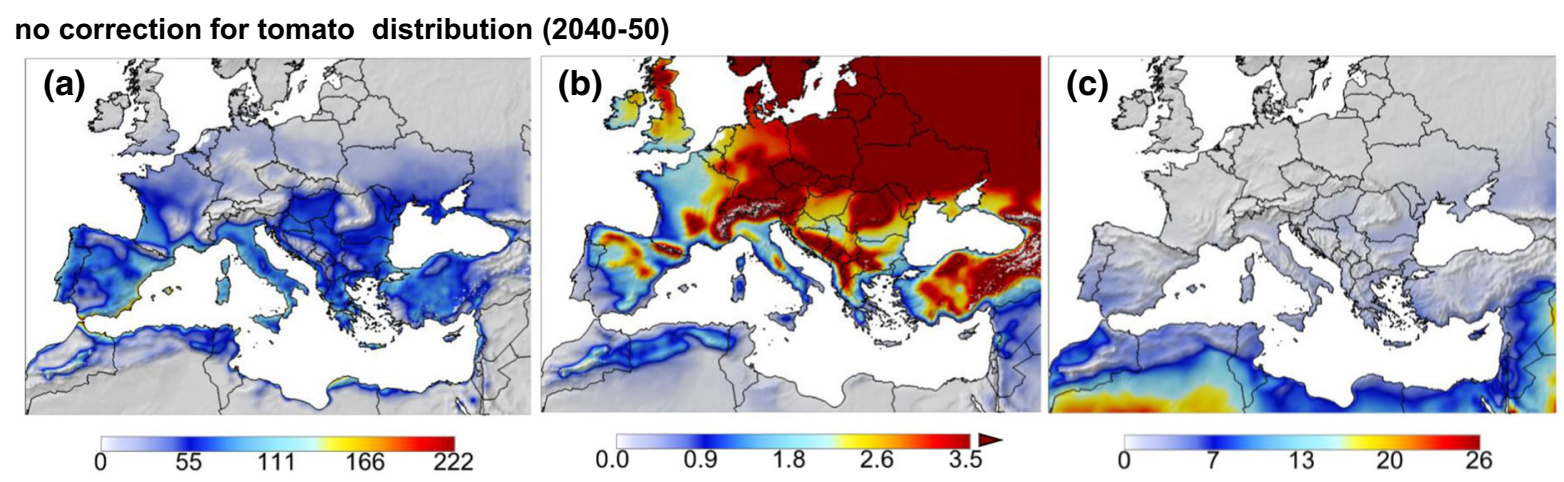

no correction for tomato distribution (2045-75)
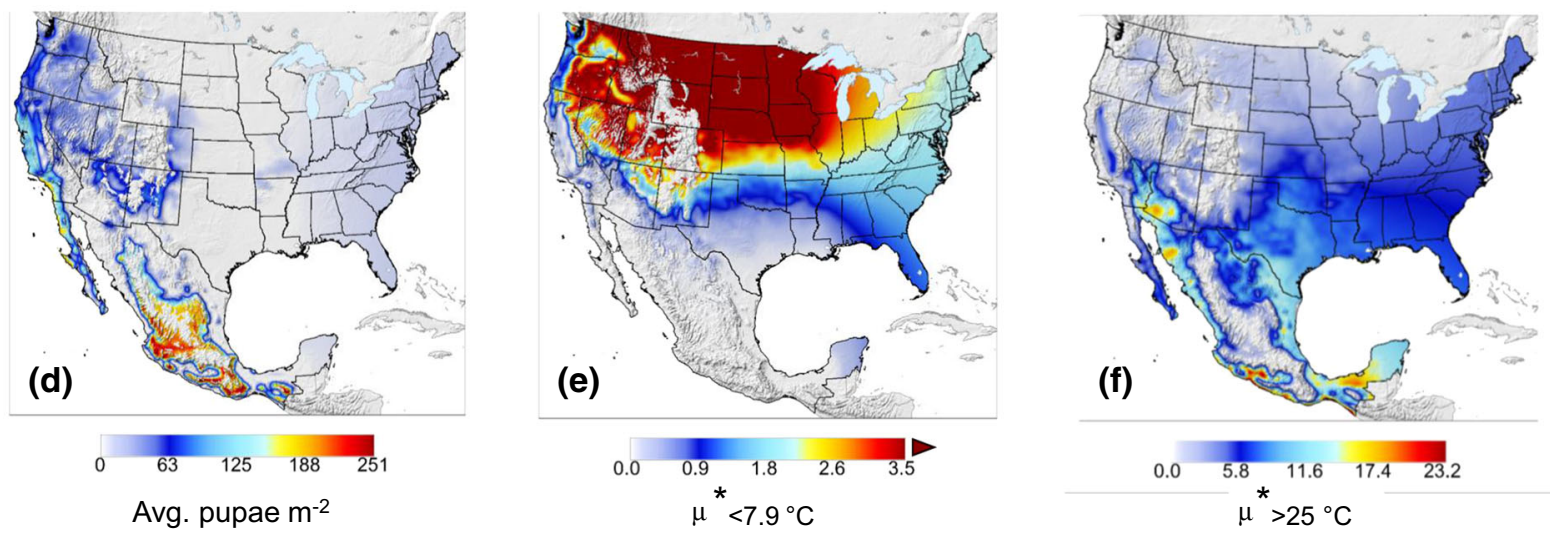

Fig. 6 Distribution, relative abundance, and low- and hightemperature mortality of T. absoluta under climate change in the Euro-Mediterranean region, USA, and Mexico. Average distribution and relative abundance of $T$. absoluta pupae using climate model weather data for Europe and the Mediterranean basin during the period 2040-2050 (top row: a, b, c) and for the

favorable (Fig. 7a), this despite the pest having been recorded from central Europe (Desneux et al. 2010) (Fig. 7b and SI, Fig. S3).

Similarly, the second CLIMEX model analysis in 2019 (Han et al. 2019) was unable to predict most areas of known occurrence of $T$. absoluta in Europe (SI, Fig. S4). The same year, a third CLIMEX analysis with insights of its invaded range (Santana et al. 2019) used a lower thermal threshold of $7{ }^{\circ} \mathrm{C}$ and a wider optimal range for development $\left(14-25^{\circ} \mathrm{C}\right)$ based on data from Martins et al. (2016) not included in the previous CLIMEX studies (Fig. 8a and b, SI, Fig. S4). This analysis predicted a Euro-Mediterranean and North American range for T. absoluta that compares favorably with the predictions of our PBDM (Fig. 8c and d, SI Figs. S5, S6; see below). Note that the PBDM has a finer scale for the index of favorability, did not
USA and Mexico during 2045-2075 (bottom row: d, e, f). Each row shows average cumulative pupal density $(\mathbf{a}, \mathbf{d})$, average yearly cumulative mortality rates for low temperatures $\left(\mu_{<7.9^{\circ} \mathrm{C}}^{*}\right)$ with values $\geq 3.5$ in dark red $(\mathbf{b}, \mathbf{e})$, and average yearly cumulative mortality rates for high temperatures $\left(\mu_{>25^{\circ} \mathrm{C}}^{*}\right)(\mathbf{c}, \mathbf{f})$

require occurrence data, and the full population dynamics for any location are available (e.g., Fig. 2).

Additional major limitations of the CLIMEX approach (Elith 2017) and by extension other correlative approaches used for assessing invasive species risk (Yates et al. 2018), include the lack of information about the phenology and vital rates that determine the population dynamics of species. These limitations preclude a detailed understanding of the observed distribution and relative abundance, and hence limit their transferability in geographic space and time to new areas and/or under climate change (Yates et al. 2018). Because correlative methods rely on occurrence records to assess invasive potential, suitable records capturing the full range of plasticity to environmental variables may not be available until 


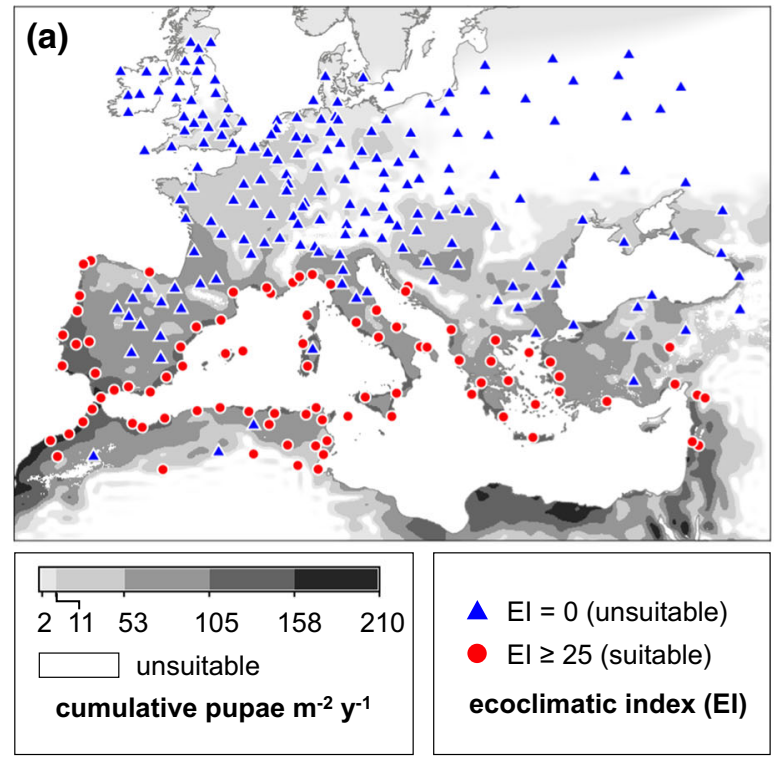

Fig. 7 Correlative risk assessment and observed distribution of T. absoluta in Europe and the Mediterranean Basin (symbols) compared with PBDM risk assessment of the species in the same region (shaded grey areas). a Distribution of the correlative ecoclimatic index (EI) of favorability for T. absoluta (blue triangle, $\mathrm{EI}=0$; red circle, $\mathrm{EI} \geq 25$ ) from the first CLIMEX assessment by Desneux et al. (2010) superimposed on the average cumulative number of pupae $\mathrm{m}^{-2}$ year $^{-1}$ predicted by the mechanistic PBDM for 1990-2010 without correction for

after the potential invasive range of an invasive species has been occupied.

Rossini et al. (2019) modeled the temperaturedependent age-structured dynamics of T. absoluta, but did not include leaf-mine microclimate or temperature-dependent mortality, and did not attempt assessment of its geographic distribution. Our mechanistic PBDM representation of the weather-driven biology and age-structured population dynamics (Gutierrez 1996) of T. absoluta captures the full range of its thermal biology, including the effects of relative humidity and solar radiation on microclimate temperatures experienced by the larvae and pupae inside leaf mines. Unlike correlative methods, PBDMs are not biased by the species' range or by spatial autocorrelation in climatic and distribution data (Journé et al. 2019; Briscoe et al. 2019). These attributes make our PBDM transferable to novel locations and conditions. Further, the PBDM for Tuta required no calibration, because the weather-driven biodemographic functions captured the moth's biology. When used in a GIS context as done here, PBDMs bridge the gap between

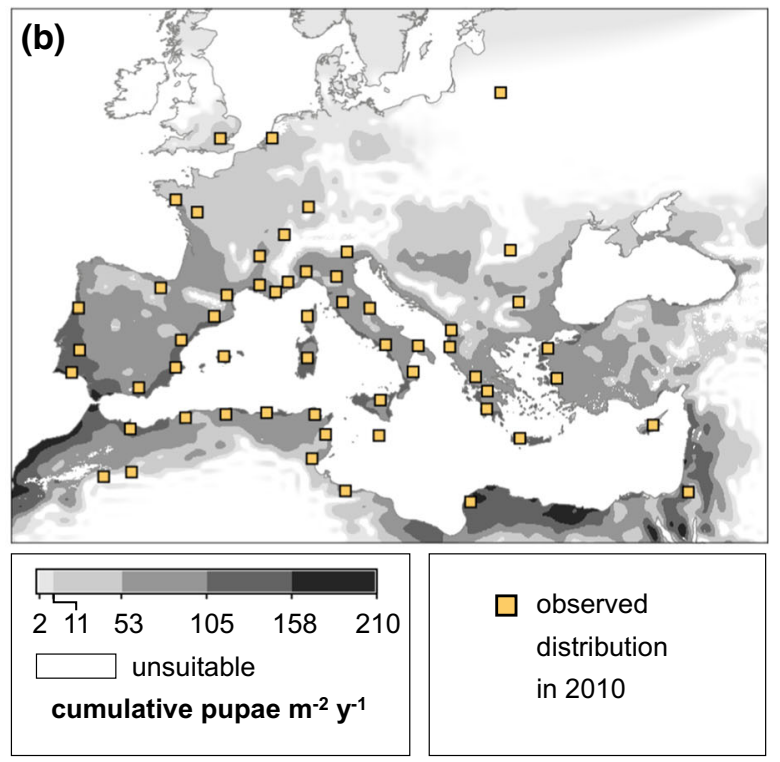

tomato distribution (grayscale area). b Observed distribution of T. absoluta in 2010 (Desneux et al. 2010) superimposed on the same grayscale PBDM predictions shown in (a). The CLIMEX model mapped in (a) was based on limited knowledge of thermal biology and invaded range (i.e., occurrence records from South America and Europe up to early 2008). EI is scaled from 0 to 100 for degrees of climatic suitability with unsuitable (0-25) to increasingly suitable $(\geq 25-100)$ locations (Desneux et al. 2010). Further detail is reported in SI, Fig. S3

bottom-up (e.g., field experiments) and top-down approaches (e.g., correlative ecological niche methods) to invasive species assessment (see SI, Discussion and Fig. S7).

Temperature is a dominant driver of T. absoluta dynamics, and recently Kahrer et al. (2019) and Campos et al. (2020) explored the biology in a range of low temperatures critical for assessing its overwintering survival in temperate regions, and hence its prospective geographic range and relative abundance. The moth's modest developmental threshold $\left(7.9^{\circ} \mathrm{C}\right)$, and facultative diapause (Campos et al. 2020), combined with its high degree of cold hardiness (Kahrer et al. 2019) enable its northward range expansion that is ultimately limited by cold in northern areas roughly delimited at $\mu_{<7.9^{\circ} \mathrm{C}}^{*} \sim 3.5$. In southern areas, high temperatures affect reproduction and survival rates, particularly in hot-dry desert areas of North Africa, USA, and Mexico.

Had adequate data been available, and a PBDMbased pest risk analysis (Gutierrez 1996; Ponti et al. $2015 \mathrm{a}, \mathrm{b}$ ) been performed before T. absoluta invaded 

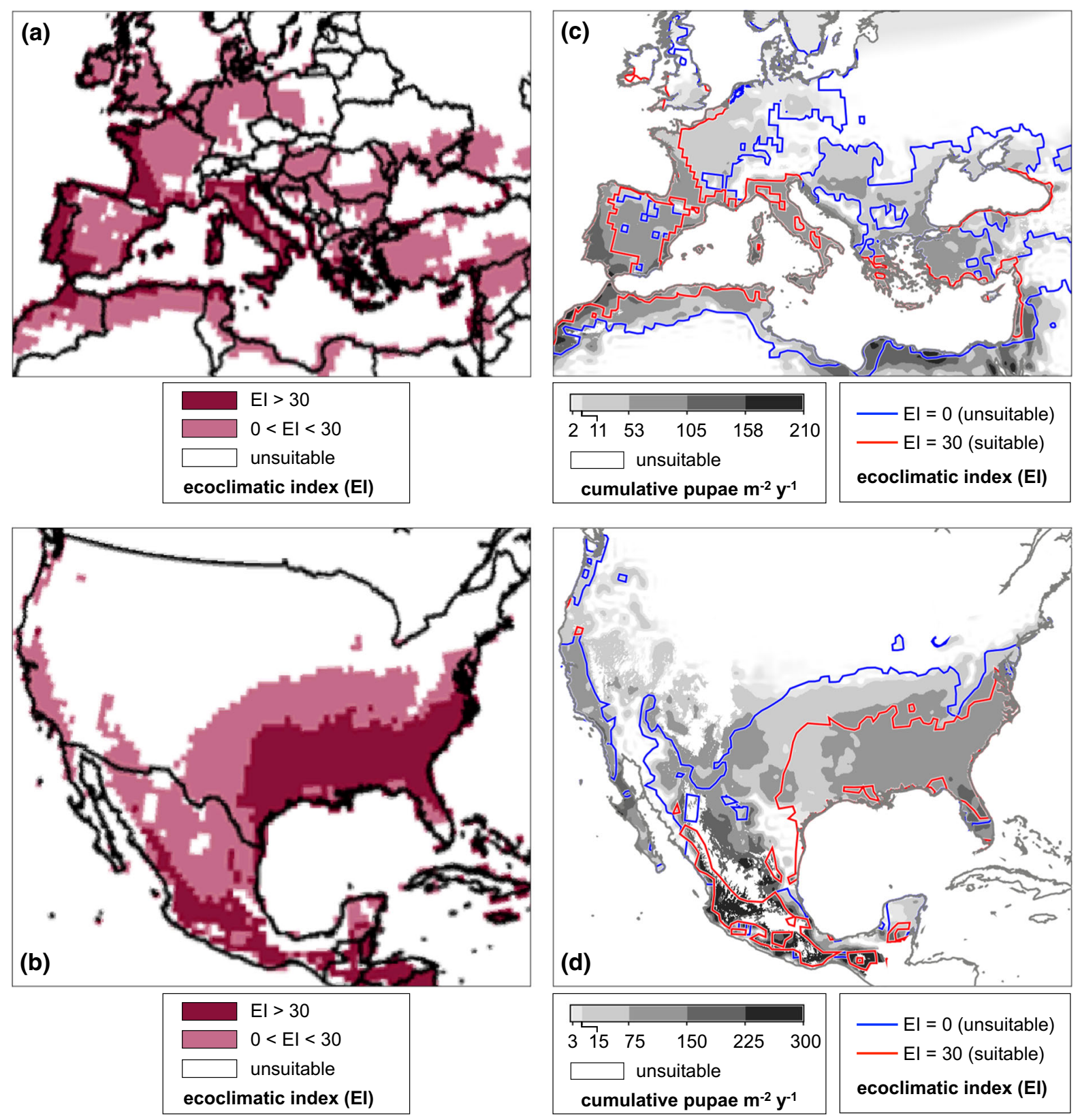

Fig. 8 Comparing correlative and PBDM risk assessment of $T$. absoluta in Europe and the Mediterranean Basin and prospectively in the USA and Mexico. Distribution of the ecoclimatic index (EI) of favorability for T. absoluta in Europe and the Mediterranean basin (a) and in the USA and Mexico (b) from the third CLIMEX assessment developed by Santana et al. (2019). The same EI distribution represented as isolines for $\mathrm{EI}=0$ (blue) and $\mathrm{EI}=30$ (red) superimposed on the average cumulative number of pupae $\mathrm{m}^{-2}$ year $^{-1}$ predicted by the PBDM for 1990-2010 without correction for tomato

distribution (grayscale area) in the Euro-Mediterranean region (c), and in the USA and Mexico (d). The Santana et al. (2019) CLIMEX assessment was based on improved knowledge of the thermal biology and invaded range (i.e., occurrence records from Central and South America, Europe, Africa, and Asia updated to 2017). EI is scaled from 0 to 100 for degrees of climatic suitability with unsuitable $(E I=0)$ to marginally suitable $(0<\mathrm{EI}<30)$ to highly suitable $(\mathrm{EI} \geq 30)$ locations (Santana et al. 2019). Further detail in SI, Figs. S4-S6 
Spain in 2006, the invasion risk would have been identified for vast areas of Europe, and for North America, and other areas globally, targeting this species as a regulatable quarantine pest. This could have prevented its introduction, and rapid global invasion. Postharvest controls of tomato using storage at high $\left[\mathrm{CO}_{2}\right]$ and low temperature (Riudavets et al. 2016) could have prevented its crossing of the ocean barrier to Spain. However, once established in Spain, quarantine measures proved ineffective, as range expansion in Europe, Africa, and Asia (Desneux et al. 2010) was aided by human spread (McNitt et al. 2019) and likely by its ability for long wind-assisted flight dispersal (Desneux et al. 2010; Biondi et al. 2018) as documented for another moth in the same Family Gelechiidae, the pink bollworm Pectinophora gossypiella (Stern and Sevacherian 1978).

The invasive range of $T$. absoluta now includes many developing countries that are under-resourced to implement policies for preventing and managing biological invasions (Measey et al. 2019). In eight years, the species invaded the whole African continent (Biondi et al. 2018; Biondi and Desneux 2019) where it threatens the food security and livelihoods of subsistence farmers of solanaceous crops (Pratt et al. 2017; Aigbedion-Atalor et al. 2019). In East Africa alone, estimated annual losses to T. absoluta in mixed small farming systems are estimated to be 69.6-79.4 million USD (Pratt et al. 2017). Similar threats to food security and estimates of high economic losses occur in developing Asian countries (Biondi et al. 2018; Bahadur and Bikram 2019; Biondi and Desneux 2019; Han et al. 2019). The majority of farmers in Africa and Asia are smallholders (Hruska 2019), most of whom before recent major biological invasions such as $T$. absoluta and Spodoptera frugiperda, used no pesticides (Rwomushana et al. 2019; Hruska 2019).

\section{Conclusions}

Global society must do a better job of preventing and mitigating biological invasions that may only worsen under global change. The first tasks are to identify and characterize the risk posed; secondly, to institute measures for preventing their introduction; and thirdly, to have institutions and mechanisms to control them if introductions occur. Some species, however, may be particularly difficult to identify as risks, as they may expand their host range and increase their invasive potential only after invasion when released from native biotic regulation, as occurred with klamath weed (Hypericum perforatum), cottony cushion scale (Icerya purchasi), and cassava mealybug (Phenacoccus manihoti)—species that were quickly brought under biological control (Huffaker and Messenger 1976; Herren and Neuenschwander 1991). However, known pests of crops that are grown globally should be characterized and analyzed as potential invasive pests: T. absoluta is a bellwether case.

Given identification of risk, the PBDM approach offers a solid mechanistic pest risk assessment (Ponti et al. 2015a) of invasive species (Ponti et al. 2015b) lacking in most correlative approaches used to predict biological invasions (Novoa et al. 2020). Specifically, PBDMs have similar subcomponents (Gutierrez and Ponti 2013) that speed up identification of gaps in biological data and streamline data collection (Ponti et al. 2015a), and require relatively modest data and funding to parameterize and develop sound mechanistic descriptions of the biology of an invasive species (Gutierrez and Ponti 2013). In contrast to correlative ENMs (Yates et al. 2018), well parameterized PBDMs are transferable and can be used to gauge the invasiveness of species in new areas and/or under climate change using management-relevant metrics such as their phenology, relative abundance, and geographic distribution-before invasion occurs (e.g., North and Central America). PBDMs inform the biological mechanisms for the geographic distribution of species, including their prospective invasive range.

Compared to phenological models such as that developed by Suppo et al. (2020) for the invasive box tree moth Cydalima perspectalis, PBDMs enable assessing age-structured population dynamics that have distributed maturation times and are driven by temperature (including extremes), humidity, and other factors (e.g., nutrition) with time-varying effects on development, reproduction, and mortality-in addition to phenology. Because PBDMs generalize the biology of species across trophic levels using ecological analogies (Gutierrez 1996), they capture the biology of an invasive (or any) species in a detailed mechanistic way using a similar or lower number of parameters than used by phenological models or ENMs. Ecological complexity is tackled at the conceptual level and hence does not result in an increased 
number of parameters. This also enable explicitly accounting for interactions with other species in a mechanistic way (e.g., Gutierrez et al. 2005, 2017).

The PBDM approach addresses the ongoing lack of an effective (Ricciardi et al. 2017) and unified method (Dick et al. 2017) to assess and manage invasive species under climate change (Lehmann et al. 2020); a deficiency that has prevented invasion biology from becoming a more predictive science (Cuthbert et al. 2019). PBDM methods are applicable to potential invasive species of any taxa and can help unify the currently fragmented invasion science landscape (Dick et al. 2017) based on a physiologically-based paradigm of ecological analogies (Gutierrez 1996). The PBDM approach is not limited to terrestrial ecosystems (d'Oultremont and Gutierrez 2002) and can be extended to support ecological risk modeling in aquatic ecosystems (see e.g., Solovjova 2019). By design (Gutierrez and Ponti 2013), PBDM analyses would help address key open questions for devising management strategies for T. absoluta and other invasive species, which rate is increasing across most taxa (Seebens et al. 2017). We must and can do a better job of mitigating biological invasions under global change, but this requires commitment and readjustments of priorities in responsible agencies-it requires investigating the holistic biology of potential invasive species (see Campos et al. 2020).

Acknowledgements $\mathrm{We}$ are grateful to the international network of developers who maintain and continue to improve the Geographic Resources Analysis Support System (GRASS, https://grass.osgeo.org) GIS software and make it available to the scientific community. We thank Bridget Thrasher from the Climate Analytics Group (http://www.climateanalyticsgroup. org) for help in obtaining the NASA climate model weather data. The climate scenario for the USA and Mexico are from the NEX-GDDP dataset, prepared by the Climate Analytics Group and NASA Ames Research Center using the NASA Earth Exchange, and distributed by the NASA Center for Climate Simulation (NCCS). The climate scenario for the EuroMediterranean region was developed and provided by the Laboratorio Modellistica Climatica e Impatti at ENEA, Rome, Italy.

Authors' contribution LP and APG conceived and designed the work, performed the PBDM/GIS analysis, and wrote the initial draft of the manuscript. MRC and ND contributed biological data for T. absoluta. MN performed GIS analysis of CLIMEX studies, enabling comparisons of PBDM and CLIMEX maps. All authors contributed to the interpretation of data, substantively revised the manuscript, and have approved the submitted version.
Funding Open access funding provided by Ente per le Nuove Tecnologie, l'Energia e l'Ambiente within the CRUI-CARE Agreement. This research was supported by the Center for the Analysis of Sustainable Agricultural Systems Global (CASAS Global, http://www.casasglobal.org/), by Agenzia nazionale per le nuove tecnologie, l'energia e lo sviluppo economico sostenibile (ENEA), Rome, Italy, by the project MED-GOLD that received funding from the European Union's Horizon 2020 research and innovation programme under grant agreement No 776467, and by the IPM Innovation Lab (USAID Cooperative Agreement No. AID-OAA-L-15-00001) for funding to N.D.

Data availability All data used in the analysis are publicly available or were sourced from the scientific literature (see Materials and Methods).

Code availability The source code for this PBDM is in Borland Pascal code that is embedded in a larger system base that includes PBDMs for 40 different species of plants, herbivores, parasitoids, predators, and pathogens that have been published as PBDM analyses based on the same methods and implemented in a GIS context (e.g., Gutierrez and Ponti 2014). These models are currently undergoing recoding in Python using an object-oriented programming paradigm for release as open source (Ponti et al. 2019).The mechanistic PBDM for T. absoluta was developed based on data available in the literature, and is similar to the model developed for the light brown apple moth Epiphyas postvittana (Gutierrez et al. 2010). Like the other PBDMs developed in the last three decades, the Pascal code for the T. absoluta PBDM is not licensed nor it is deposited in a code repository, and is managed by the nonprofit scientific consortium Center for the Analysis of Sustainable Agricultural Systems Global (CASAS Global, http://www. casasglobal.org/). The PBDM algorithms as well as key innovative code for the distributed maturation time models with and without attrition, have been published (Gutierrez 1996, page 157).

\section{Declarations}

Conflict of interest The authors have no conflicts of interest.

Open Access This article is licensed under a Creative Commons Attribution 4.0 International License, which permits use, sharing, adaptation, distribution and reproduction in any medium or format, as long as you give appropriate credit to the original author(s) and the source, provide a link to the Creative Commons licence, and indicate if changes were made. The images or other third party material in this article are included in the article's Creative Commons licence, unless indicated otherwise in a credit line to the material. If material is not included in the article's Creative Commons licence and your intended use is not permitted by statutory regulation or exceeds the permitted use, you will need to obtain permission directly from the copyright holder. To view a copy of this licence, visit http://creativecommons.org/licenses/by/4.0/. 


\section{References}

Aigbedion-Atalor PO, Hill MP, Zalucki MP et al (2019) The South America tomato leafminer, Tuta absoluta (Lepidoptera: Gelechiidae), spreads its wings in eastern Africa: distribution and socioeconomic impacts. J Econ Entomol 112:2797-2807. https://doi.org/10.1093/jee/toz220

Alvares CA, Stape JL, Sentelhas PC et al (2013) Köppen's climate classification map for Brazil. Meteorol $\mathrm{Z}$ 22:711-728. https://doi.org/10.1127/0941-2948/2013/ 0507

Artale V, Calmanti S, Carillo A et al (2010) An atmosphereocean regional climate model for the Mediterranean area: assessment of a present climate simulation. Clim Dyn 35:721-740. https://doi.org/10.1007/s00382-009-0691-8

Bahadur CL, Bikram A (2019) Fall armyworm (Spodoptera frugiperda): a threat to food security for south Asian country: control and management options: a review. Farm Manag 4:38-44. https://doi.org/10.31830/2456-8724. 2019.004

Barrientos ZR, Apablaza HJ, Norero SA, Estay P Patricia (1998) Temperatura base y constante termica de desarrollo de la polilla del tomate, Tuta absoluta (Lepidoptera: Gelechiidae). Ciencia e Investigación Agraria 25:133-137

Baumgärtner J, Severini M (1987) Microclimate and arthropod phenologies: the leaf miner Phyllonorycter blancardella F. (Lep.) as an example. In: Prodi F, Rossi F, Cristoferi G (eds) Agrometeorology: 2nd International Cesena Agricultura Conference, Cesena, 8-9 October 1987. Comune di Cesena, Cesena, Italy, pp 225-243

Bentancourt CM, Scatoni IB, Rodríguez JJ (1996) Influencia de la temperatura sobre la reproducción y el desarrollo de Scrobipalpuloides absoluta (Meyrick)(Lepidoptera, Gelechiidae). Rev Bras Biol 56:661-670

Bieri M, Baumgärtner J, Bianchi G et al (1983) Development and fecundity of pea aphid (Acyrthosiphon pisum Harris) as affected by constant temperatures and by pea varieties. Mitt Schweiz Entomol Ges 56:163-171. https://doi.org/10. 5169/seals-402070

Biondi A, Desneux N (2019) Special issue on Tuta absoluta: recent advances in management methods against the background of an ongoing worldwide invasion. J Pest Sci 92:1313-1315. https://doi.org/10.1007/s10340-01901132-6

Biondi A, Guedes RNC, Wan F-H, Desneux N (2018) Ecology, worldwide spread, and management of the invasive South American tomato pinworm, Tuta absoluta: past, present, and future. Annu Rev Entomol 63:239-258. https://doi. org/10.1146/annurev-ento-031616-034933

Blanca J, Montero-Pau J, Sauvage C et al (2015) Genomic variation in tomato, from wild ancestors to contemporary breeding accessions. BMC Genomics 16:257. https://doi. org/10.1186/s12864-015-1444-1

Bradshaw CJA, Leroy B, Bellard C et al (2016) Massive yet grossly underestimated global costs of invasive insects. Nat Commun. https://doi.org/10.1038/ncomms12986

Briére JF, Pracros P, Le Roux AY, Pierre JS (1999) A novel rate model of temperature-dependent development for arthropods. Environ Entomol 28:22-29. https://doi.org/10.1093/ ee/28.1.22
Briscoe NJ, Elith J, Salguero-Gómez R et al (2019) Forecasting species range dynamics with process-explicit models: matching methods to applications. Ecol Lett. 22:19401956

Buffoni G, Pasquali S (2007) Structured population dynamics: continuous size and discontinuous stage structures. J Math Biol 54:555-595. https://doi.org/10.1007/s00285-0060058-2

Campos MR, Béarez P, Amiens-Desneux E et al (2020) Thermal biology of Tuta absoluta: demographic parameters and facultative diapause. J Pest Sci. https://doi.org/10.1007/ s10340-020-01286-8.10.1007/s10340-020-01286-8

Cherif A, Attia-Barhoumi S, Mansour R et al (2019) Elucidating key biological parameters of Tuta absoluta on different host plants and under various temperature and relative humidity regimes. Entomologia Generalis 39:1-7. https:// doi.org/10.1127/entomologia/2019/0685

Climate-Data.org (2019) Huancayo climate: Average temperature, weather by month, Huancayo weather averages. https://en.climate-data.org/south-america/peru/junin/ huancayo-3326/. Accessed 24 Jun 2019

Cocco A, Serra G, Lentini A et al (2015) Spatial distribution and sequential sampling plans for Tuta absoluta (Lepidoptera: Gelechiidae) in greenhouse tomato crops. Pest Manag Sci 71:1311-1323. https://doi.org/10.1002/ps.3931

Cuthbert RN, Dickey JWE, Coughlan NE et al (2019) The Functional Response Ratio (FRR): advancing comparative metrics for predicting the ecological impacts of invasive alien species. Biol Invasions 21:2543-2547. https://doi. org/10.1007/s10530-019-02002-z

Cuthbertson AGS, Mathers JJ, Blackburn LF et al (2013) Population development of Tuta absoluta (Meyrick) (Lepidoptera: Gelechiidae) under simulated UK glasshouse conditions. Insects 4:185-197. https://doi.org/10.3390/ insects4020185

da Silva FHBB, da Silva MSL, Cavalcanti AC, Cunha TJF (2005) Principais solos do semi-árido do nordeste do Brasil. EMBRAPA, Rio de Janeiro, Brazil

d'Oultremont T, Gutierrez AP (2002) A multitrophic model of a rice-fish agroecosystem: I. A tropical fishpond food web. Ecol Model 156:123-142. https://doi.org/10.1016/S03043800(02)00129-1

Krechemer FS, Foerster LA (2015) Tuta absoluta (Lepidoptera: Gelechiidae): thermal requirements and effect of temperature on development, survival, reproduction and longevity. Euro J Entomol. https://doi.org/10.14411/eje.2015. 103

Dell'Aquila A, Calmanti S, Ruti P et al (2012) Effects of seasonal cycle fluctuations in an A1B scenario over the EuroMediterranean region. Clim Res 52:135-157. https://doi. org/10.3354/cr01037

Desneux N, Wajnberg E, Wyckhuys K et al (2010) Biological invasion of European tomato crops by Tuta absoluta: ecology, geographic expansion and prospects for biological control. J Pest Sci 83:197-215

Di Cola G, Gilioli G, Baumgärtner J (1999) Mathematical models for age-structured population dynamics. In: Huffaker CB, Gutierrez AP (eds) Ecological entomology. Wiley, New York, USA

Dick JTA, Alexander ME, Ricciardi A et al (2017) Functional responses can unify invasion ecology. Biol Invasions 
19:1667-1672. https://doi.org/10.1007/s10530-016-13553

Elith J (2017) Predicting distributions of invasive species. In: Robinson AP, Walshe T, Burgman MA, Nunn M (eds) Invasive species. Cambridge University Press, Cambridge, pp 93-129

Eyring V, Cox PM, Flato GM et al (2019) Taking climate model evaluation to the next level. Nat Clim Chang 9:102-110. https://doi.org/10.1038/s41558-018-0355-y

Fitzpatrick EA, Nix HA (1970) The climatic factor in Australian grasslands ecology. In: Moore RM (ed) Australian Grasslands. Australian National University Press, Canberra, Australia, pp 3-26

Giorgi F, Bi X (2005) Updated regional precipitation and temperature changes for the 21 st century from ensembles of recent AOGCM simulations. Geophys Res Lett 32:L21715. https://doi.org/10.1029/2005GL024288

Gomide EVA, Vilela EF, Picanço M (2001) Comparação de procedimentos de amostragem de Tuta absoluta (Meyrick) (Lepidoptera: Gelechiidae) em tomateiro estaqueado. Neotrop Entomol 30:697-705

GRASS Development Team (2020) Geographic Resources Analysis Support System (GRASS) Software, Version 7.9.dev. Open Source Geospatial Foundation. URL http:// grass.osgeo.org, Beaverton, Oregon, USA

Gualdi S, Somot S, Li L et al (2013) The CIRCE simulations: regional climate change projections with realistic representation of the Mediterranean sea. Bull Amer Meteor Soc 94:65-81. https://doi.org/10.1175/BAMS-D-11-00136.1

Guillemaud T, Blin A, Le Goff I et al (2015) The tomato borer, Tuta absoluta, invading the Mediterranean Basin, originates from a single introduction from Central Chile. Sci Rep 5:8371. https://doi.org/10.1038/srep08371

Guimapi RYA, Mohamed SA, Okeyo GO et al (2016) Modeling the risk of invasion and spread of Tuta absoluta in Africa. Ecol Complex 28:77-93. https://doi.org/10.1016/j. ecocom.2016.08.001

Gutierrez AP (1992) The physiological basis of ratio-dependent predator-prey theory: the metabolic pool model as a paradigm. Ecology 73:1552-1563. https://doi.org/10.2307/ 1940008

Gutierrez AP (1996) Applied population ecology: a supply-demand approach. John Wiley and Sons, New York, USA

Gutierrez AP, Ponti L (2013) Eradication of invasive species: why the biology matters. Environ Entomol 42:395-411. https://doi.org/10.1603/EN12018

Gutierrez AP, Ponti L (2014) Assessing and managing the impact of climate change on invasive species: the PBDM approach. In: Ziska LH, Dukes JS (eds) Invasive species and global climate change. CABI Publishing, Wallingford, UK, pp 271-288

Gutierrez AP, Yaninek JS (1983) Responses to weather of eight aphid species commonly found in pastures in southeastern Australia. Can Entomol 115:1359-1364. https://doi.org/ 10.4039/Ent1151359-10

Gutierrez AP, Nix HA, Havenstein DE, Moore PA (1974) The ecology of Aphis craccivora Koch and subterranean clover stunt virus in south-east Australia. III. A regional perspective of the phenology and migration of the cowpea aphid. J Appl Ecol 11:21-35. https://doi.org/10.2307/ 2402002
Gutierrez AP, Pitcairn MJ, Ellis CK et al (2005) Evaluating biological control of yellow starthistle (Centaurea solstitialis) in California: A GIS based supply-demand demographic model. Biol Control 34:115-131. https://doi.org/ 10.1016/j.biocontrol.2005.04.015

Gutierrez AP, Mills NJ, Ponti L (2010) Limits to the potential distribution of light brown apple moth in Arizona-California based on climate suitability and host plant availability. Biol Invasions 12:3319-3331. https://doi.org/10. 1007/s10530-010-9725-8

Gutierrez AP, Ponti L, Cristofaro M et al (2017) Assessing the biological control of yellow starthistle (Centaurea solstitialis $\mathrm{L}$ ): prospective analysis of the impact of the rosette weevil (Ceratapion basicorne (Illiger)). Agric Entomol 19:257-273. https://doi.org/10.1111/afe.12205

Gutierrez AP, Ponti L, Arias PA (2019) Deconstructing the eradication of new world screwworm in North America: retrospective analysis and climate warming effects. Med Vet Entomol 33:282-295. https://doi.org/10.1111/mve. 12362

Han P, Bayram Y, Shaltiel-Harpaz L et al (2019) Tuta absoluta continues to disperse in Asia: damage, ongoing management and future challenges. J Pest Sci 92:1317-1327. https://doi.org/10.1007/s10340-018-1062-1

Herren HR, Neuenschwander P (1991) Biological control of cassava pests in Africa. Annu Rev Entomol 36:257-283. https://doi.org/10.1146/annurev.en.36.010191.001353

Hijmans RJ (2020) raster: geographic data analysis and modeling. R package version 3.1-5. https://CRAN.R-project. org/package $=$ raster

Hruska A (2019) Fall armyworm (Spodoptera frugiperda) management by smallholders. CAB Reviews 14:043. https://doi.org/10.1079/PAVSNNR201914043

Huffaker CB, Messenger PS (eds) (1976) Theory and practice of biological control. Academic Press, New York, USA

Hughes RD, Gilbert N (1968) A model of an aphid population-a general statement. J Anim Ecol 37:553-563. https://doi. org/10.2307/3074

IIASA II for ASA, FAO F and AO of the UN (2012) Global Agro-ecological Zones (GAEZ v.30). IIASA, Laxenburg, Austria and FAO Rome, Italy

IPCC Intergovernmental Panel on Climate Change (2014) Climate change 2014: Impacts, Adaptation, and Vulnerability. Part A: global and sectoral aspects. Contribution of Working Group II to the Fifth Assessment Report of the Intergovernmental Panel on Climate Change. Cambridge University Press, Cambridge, United Kingdom and New York, NY, USA

Journé V, Barnagaud J-Y, Bernard C et al (2019) Correlative climatic niche models predict real and virtual species distributions equally well. Ecology. https://doi.org/10.1002/ ecy.2912.10.1002/ecy.2912

Kahrer A, Moyses A, Hochfellner L et al (2019) Modelling time-varying low-temperature induced mortality rates for pupae of Tuta absoluta (Gelechiidae, Lepidoptera). J Appl Entomol 143:1143-1153. https://doi.org/10.1111/jen. 12693

Kahrer A (2015) Predicting overwintering survival and establishment of exotic pest insects under future Austrian climatic conditions. Climate and Energy Fund, Vienna, Austria 
Krechemer FS, Foerster LA (2017) Development, reproduction, survival, and demographic patterns of Tuta absoluta (Meyrick) (Lepidoptera: Gelechiidae) on different commercial tomato cultivars. Neotrop Entomol. https://doi.org/ 10.1007/s13744-017-0511-5.10.1007/s13744-017-0511-5

Lehmann P, Ammunét T, Barton M et al (2020) Complex responses of global insect pests to climate warming. Front Ecol Environ. https://doi.org/10.1002/fee.2160.10.1002/ fee. 2160

Lenzner B, Leclère D, Franklin O et al (2019) A framework for global twenty-first century scenarios and models of biological invasions. Bioscience 69:697-710. https://doi.org/ 10.1093/biosci/biz070

Li X, Li D, Zhang Z et al (2020) Supercooling capacity and cold tolerance of the South American tomato pinworm, Tuta absoluta, a newly invaded pest in China. J Pest Sci. https:// doi.org/10.1007/s10340-020-01301-y.10.1007/s10340020-01301-y

Manetsch TJ (1976) Time-varying distributed delays and their use in aggregative models of large systems. IEEE Trans Syst Man Cybern 6:547-553. https://doi.org/10.1109/ TSMC.1976.4309549

Marcano R (1995) Efecto de la temperatura sobre el desarrollo y la reproducción de Scrobipalpula absoluta (Meyrick) (Lepidoptera: Gelechiidae). Bol Entomol Venez 10:69-75

Marchioro CA, Krechemer FS, Foerster LA (2017) Estimating the development rate of the tomato leaf miner, Tuta absoluta (Lepidoptera: Gelechiidae) using linear and nonlinear models. Pest Manag Sci 73:1486-1493. https://doi. org/10.1002/ps.4484

Martins JC, Picanço MC, Bacci L et al (2016) Life table determination of thermal requirements of the tomato borer Tuta absoluta. J Pest Sci. https://doi.org/10.1007/s10340-0160729-8.10.1007/s10340-016-0729-8

McNitt J, Chungbaek YY, Mortveit H et al (2019) Assessing the multi-pathway threat from an invasive agricultural pest: Tuta absoluta in Asia. Proc Royal Soc B Biol Sci 286:20191159. https://doi.org/10.1098/rspb.2019.1159

Measey J, Visser V, Dgebuadze Y et al (2019) The world needs BRICS countries to build capacity in invasion science. PLoS Biol 17:e3000404. https://doi.org/10.1371/journal. pbio.3000404

Melo P (1992) Tomato industry in Brazil. Acta Hortic. https:// doi.org/10.17660/ActaHortic.1992.301.5

Miranda MMM, Picanço M, Zanuncio JC, Guedes RNC (1998) Ecological life table of Tuta absoluta (Meyrick) (Lepidoptera: Gelechiidae). Biocontrol Sci Tech 8:597-606. https://doi.org/10.1080/09583159830117

Neteler M, Bowman MH, Landa M, Metz M (2012) GRASS GIS: a multi-purpose open source GIS. Environ Model Softw 31:124-130. https://doi.org/10.1016/j.envsoft.2011. 11.014

Newville M, Stensitzki T, Allen DB, Ingargiola A (2014) LMFIT: non-linear least-square minimization and curvefitting for Python. Zenodo. https://doi.org/10.5281/zenodo. 11813

Novoa A, Richardson DM, Pyšek P et al (2020) Invasion syndromes: a systematic approach for predicting biological invasions and facilitating effective management. Biol Invasions. https://doi.org/10.1007/s10530-020-02220-w. 10.1007/s10530-020-02220-w
Özgökçe MS, Bayındır A, Karaca İ (2016) Temperature-dependent development of the tomato leaf miner, Tuta absoluta (Meyrick) (Lepidoptera: Gelechiidae) on tomato plant Lycopersicon esculentum Mill. (Solanaceae). Turk J Entomol 40:51-59. https://doi.org/10.16970/ted.64743

Pincebourde S, Casas J (2006) Multitrophic biophysical budgets: thermal ecology of an intimate herbivore insect-plant interaction. Ecol Monogr 76:175-194. https://doi.org/10. 1890/0012-9615(2006)076[0175:MBBTEO]2.0.CO;2

Ponti L, Gutierrez AP, Ruti PM, Dell'Aquila A (2014) Finescale ecological and economic assessment of climate change on olive in the Mediterranean Basin reveals winners and losers. Proc Nat Acad Sci USA 111:5598-5603. https://doi.org/10.1073/pnas.1314437111

Ponti L, Gilioli G, Biondi A et al (2015a) Physiologically based demographic models streamline identification and collection of data in evidence-based pest risk assessment. EPPO Bull 45:317-322. https://doi.org/10.1111/epp.12224

Ponti L, Gutierrez AP, Altieri MA (2015b) Holistic approach in invasive species research: the case of the tomato leaf miner in the Mediterranean Basin. Agroecol Sustain Food Syst 39:436-468. https://doi.org/10.1080/21683565.2014. 990074

Ponti L, Gutierrez AP, Cure JR, et al (2019) Bioeconomic analogies as a unifying paradigm for modeling agricultural systems under global change in the context of geographic information systems. Geophys Res Abstracts 21:EGU2019-13677. https://meetingorganizer. copernicus.org/EGU2019/EGU2019-13677.pdf

Pratt CF, Constantine KL, Murphy ST (2017) Economic impacts of invasive alien species on African smallholder livelihoods. Glob Food Sec 14:31-37. https://doi.org/10.1016/j. gfs.2017.01.011

R Core Team (2020) R: a language and environment for statistical computing. R Foundation for Statistical Computing, Vienna, Austria. URL http://www.R-project.org

Reaumur RAF de (1735) Observation du thermomètre faites à Paris pendant l'année 1735 comparées avec celles qui ont été faites sous la ligne, à l'Ile de France, à Alger et en quelques-unes de nos Iles de l'Amérique. Mémoires de l'Académie des Sciences, Paris 545-576

Riahi K, Rao S, Krey V et al (2011) RCP 8.5-A scenario of comparatively high greenhouse gas emissions. Clim Change 109:33-57. https://doi.org/10.1007/s10584-0110149-y

Ricciardi A, Blackburn TM, Carlton JT et al (2017) Invasion science: a horizon scan of emerging challenges and opportunities. Trends Ecol Evol 32:464-474. https://doi. org/10.1016/j.tree.2017.03.007

Rienecker MM, Suarez MJ, Gelaro R et al (2011) MERRA: NASA's Modern-Era retrospective analysis for research and applications. J Climate 24:3624-3648. https://doi.org/ 10.1175/JCLI-D-11-00015.1

Riudavets J, Alonso M, Gabarra R et al (2016) The effects of postharvest carbon dioxide and a cold storage treatment on Tuta absoluta mortality and tomato fruit quality. Postharvest Biol Technol 120:213-221. https://doi.org/10.1016/j. postharvbio.2016.06.015

Rogelj J, Meinshausen M, Knutti R (2012) Global warming under old and new scenarios using IPCC climate sensitivity 
range estimates. Nat Clim Chang 2:248-253. https://doi. org/10.1038/Nclimate1385

Rossini L, Severini M, Contarini M, Speranza S (2019) A novel modelling approach to describe an insect life cycle vis-àvis plant protection: description and application in the case study of Tuta absoluta. Ecol Model 409:108778. https:// doi.org/10.1016/j.ecolmodel.2019.108778

Ruane AC, Goldberg R, Chryssanthacopoulos J (2015) Climate forcing datasets for agricultural modeling: Merged products for gap-filling and historical climate series estimation. Agric for Meteorol 200:233-248. https://doi.org/10.1016/j. agrformet.2014.09.016

Rwomushana I, Beale T, Chipabika G, et al (2019) Tomato leafminer (Tuta absoluta): impacts and coping strategies for Africa. CABI Working Paper 12:56pp. https://doi.org/ 10.1079/CABICOMM-62-8100

Sager JC, McFarlane JC (1997) Chapter 1 - Radiation. In: Langhans RW, Tibbitts TW (eds) Plant Growth Chamber Handbook. Iowa State University, USA

Santana PA, Kumar L, Da Silva RS, Picanço MC (2019) Global geographic distribution of Tuta absoluta as affected by climate change. J Pest Sci 92:1373-1385. https://doi.org/ 10.1007/s10340-018-1057-y

Seebens H, Blackburn TM, Dyer EE et al (2017) No saturation in the accumulation of alien species worldwide. Nat Commun 8:14435. https://doi.org/10.1038/ncomms14435

Sheffield J, Barrett AP, Colle B et al (2013) North American climate in CMIP5 experiments. part I: evaluation of historical simulations of continental and regional climatology. J Climate 26:9209-9245. https://doi.org/10.1175/JCLI-D12-00592.1

Solovjova NV (2019) Ecological risk modelling in developing resources of ecosystems characterized by varying vulnerability levels. Ecol Model 406:60-72. https://doi.org/10. 1016/j.ecolmodel.2019.05.015

Stern V, Sevacherian V (1978) Long-range dispersal of pink bollworm into the San Joaquin Valley. Calif Agric 32:4-5. https://doi.org/10.3733/ca.v032n07p4

Suppo C, Bras A, Robinet C (2020) A temperature- and photoperiod-driven model reveals complex temporal population dynamics of the invasive box tree moth in Europe. Ecol Model. https://doi.org/10.1016/j.ecolmodel.2020. 109229

Sutherst RW, Maywald GF (1985) A computerised system for matching climates in ecology. Agr Ecosyst Environ
13:281-299. 8809(85)90016-7

https://doi.org/10.1016/0167-

Sylla S, Brévault T, Monticelli LS et al (2019) Geographic variation of host preference by the invasive tomato leaf miner Tuta absoluta: implications for host range expansion. J Pest Sci 92:1387-1396. https://doi.org/10.1007/ s10340-019-01094-9

Taylor KE, Stouffer RJ, Meehl GA (2012) An overview of CMIP5 and the experiment design. Bull Amer Meteor Soc 93:485-498. https://doi.org/10.1175/BAMS-D-11-00094. 1

Thrasher B, Maurer EP, McKellar C, Duffy PB (2012) Technical Note: Bias correcting climate model simulated daily temperature extremes with quantile mapping. Hydrol Earth Syst Sci 16:3309-3314. https://doi.org/10.5194/hess-163309-2012

Torres JB, Faria CA Jr, Pratissoli D (2001) Within-plant distribution of the leaf miner Tuta absoluta (Meyrick) immatures in processing tomatoes, with notes on plant phenology. Int J Pest Manag 47:173-178

Van Damme V, Berkvens N, Moerkens R et al (2015) Overwintering potential of the invasive leafminer Tuta absoluta (Meyrick) (Lepidoptera: Gelechiidae) as a pest in greenhouse tomato production in Western Europe. J Pest Sci 88:533-541. https://doi.org/10.1007/s10340-014-0636-9

Vansickle J (1977) Attrition in distributed delay models. IEEE T Syst Man Cyb 7:635-638. https://doi.org/10.1109/TSMC. 1977.4309800

Verheggen F, Fontus RB (2019) First record of Tuta absoluta in Haiti. Entomologia Generalis. https://doi.org/10.1127/ entomologia/2019/0778

Wickham H (2016) ggplot2: elegant graphics for data analysis, 2nd edn. Springer-Verlag, New York, USA

Yates KL, Bouchet PJ, Caley MJ et al (2018) Outstanding challenges in the transferability of ecological models. Trends Ecol Evol 33:790-802. https://doi.org/10.1016/j. tree.2018.08.001

Zhang G, MaybeD., Liu W, et al (2019) The arrival of Tuta absoluta (Meyrick) (Lepidoptera: Gelechiidae), in China. J Biosaf. 28:200-203

Publisher's Note Springer Nature remains neutral with regard to jurisdictional claims in published maps and institutional affiliations. 